\title{
Collapse of the Icelandic ice sheet controlled by sea-level rise?
}

\author{
Hreggviður Norðdahl ${ }^{1}$ O Ólafur Ingólfsson ${ }^{1,2}$
}

Received: 3 September 2015/Accepted: 29 October 2015/Published online: 21 November 2015

(C) Springer-Verlag Berlin Heidelberg 2015

\begin{abstract}
The deglaciation of the Late Weichselian Icelandic ice sheet was extremely rapid, and marked by a collapse of its marine-based sections between 15.0 and $14.7 \mathrm{ka}$ BP. We present a conceptual two-dimensional glacio-isostatic equilibrium model that describes the effect of simultaneous glacio-isostatic responses to changes in glacier load on the crust and relative eustatic sea level changes during the deglaciation of the Icelandic ice sheet. The deglaciation was characterized by three main steps: (1) slow deglaciation of the outer shelf, progressing between about 18.6-15.0 ka BP, mainly driven by sea-level rise and grounding line retreat on a retrograde slope; (2) an extremely rapid retreat from the shelf areas between 15.0 and $14.7 \mathrm{ka} \mathrm{BP}$, mainly driven by rapid sea-level rise and largescale calving; (3) a slower retreat driven by North Atlantic warming once the ice sheet was inside the coast, between 14.7 and $13.8 \mathrm{ka}$ BP. The very rapid deglaciation of the Iceland shelf areas between 15.0 and $14.7 \mathrm{ka}$ BP does not confirm with linear response to warming, but rather describes a non-linear response, where the ice sheet experiences an abrupt collapse once a threshold defined by relative eustatic sea-level rise is crossed. We propose that rapid eustatic sea-level rise that peaked during Mwp-1A being coeval with the collapse of the marine-based part of
\end{abstract}

Hreggviður Norðdahl

hreggi@hi.is

Ólafur Ingólfsson

olafuri@unis.no

1 Faculty of Earth Sciences, University of Iceland, Sæmundargata 2, 101 Reykjavík, Iceland

2 The University Centre in Svalbard (UNIS), P.O. Box 156, 9171 Longyearbyen, Norway the Icelandic ice sheet suggests a causal relationship between the two events.

Keywords Icelandic ice sheet - Late Weichselian - Ice sheet collapse $\cdot$ Deglaciation $\cdot$ Sea-level rise

\section{Introduction}

The Icelandic ice sheet (IIS) and other Northern Hemisphere Pleistocene ice sheets have traditionally been regarded as slowly responding to insolation changes and climate forcing [28, 84], but recent advances in our understanding of ice sheet behaviour show that some ice sheets have responded much faster to regional and global climate changes than previously thought $[10,14]$. Although increased summer ablation, caused by rising northern latitude insolation $[1,13]$, was the primary control of initial retreat of ice sheets from their Last Glacial Maximum (LGM) positions, continued warming and deglaciation initiated rapid glacio-eustatic sea-level rise $[8,9,21,45$, 46], which may have hastened the transformation of marine-based ice sheets into floating ice shelves, which in turn may have rapidly disintegrated because of reduced ice-bed coupling, eventually leading to very fast deglaciation or ice sheet collapse [32]. Denton et al. [17] stated that Northern Hemisphere LGM ice sheets at their maximum, with marine-based sectors expanded across continental shelves with maximum isostatic depression beneath them, were prone to become unstable and collapse into the adjacent oceans, and a holistic perspective needs to consider contributing feedbacks such as global sea-level rise, ice-stream dynamics, isostatic adjustments, subglacial temperature regimes and hydrology, as well as calving dynamics. For palaeo-ice sheets the relative importance of these factors 
are poorly constrained and they remain a challenge to modellers [43].

The extremely rapid retreat of a marine-based ice sheet from the shelf around Iceland and the subsequent formation of highly elevated Marine Limit (ML) shorelines indicate that the deglaciation was the result of a collapse of the IIS rather than being the result of a long-term negative massbalance [36]. This ice sheet collapse coincided with a period of rapid relative eustatic sea-level (RESL) rise that peaked during the meltwater pulse $1 \mathrm{~A}$ (Mwp-1A) event [11, 12, 16, 21, 45, 46, 79]. Syvitski et al. [77] suggested that rapid eustatic sea-level rise was a causal factor in the rapid deglaciation, and Ingólfsson and Norðdahl [36] suggested that rapid sea-level rise most likely destabilized the ice sheet and subsequently led to its collapse. Ingólfsson and Norðdahl [36] pointed out the important role of glacioisostasy in the deglaciation scenario, as the Icelandic crust (lithosphere) and asthenosphere respond very quickly to changes in glacial loading and unloading (c.f. [72]), and suggested that the very high ML shorelines could not have formed unless the deglaciation was extremely rapid. Our aim here is to review current understanding of the deglaciation of Iceland, test the tentative suggestion of Ingólfsson and Norðdahl [36] that rapid sea-level rise destabilized the IIS and led to its collapse, and to present a hypothesis that takes into consideration variables that controlled and/or affected the sequence of events that ultimately led to the collapse of the IIS. The considered variables are time and duration of the LGM situation and the deglaciation of the shelf, age of the ML shorelines and concurrent conditions of North Atlantic Ocean currents and their pattern, and changes in RESL and glacio-isostatic position of the land.

\section{Previous research}

The main uncertainty in reconstructing the last deglaciation of Iceland has for long been the poor chronological resolution, which reflects the relative sparsity of well-dated stratigraphical sites on land and from the shelf around Iceland. Norðdahl [52] accounted for the development of the earliest models describing an uninterrupted and continuous deglaciation of the Late Weichselian IIS. He outlined how the models had developed towards recognizing single, double, and finally multi re-advance mode of deglaciation, where the ice sheet oscillations were depicted primarily as reactions to climate forcing. None of these models could explain how and why ML shorelines at relatively high altitudes were formed at about $14.7 \mathrm{ka} \mathrm{BP}$, in times of none known glacier re-advance nor any other increased loading on the crust to explain a temporary equilibrium between glacio-isostatic uplift and RESL rise facilitating formation of these shorelines. Norðdahl and Pétursson [54] and Pétursson et al. [63] compiled all available data for the maximum glacier extent on the shelf around Iceland and proposed LGM ice-marginal positions on the shelf off Iceland (Fig. 1). Spagnolo and Clark [75] analyzed data from the Olex sea floor bathymetry database and recognized moraine-like features on the shelf around Iceland, much in agreement with the earlier research. Hubbard [30] and Hubbard et al. [31] modelled a LGM ice sheet using a three-dimensional thermomechanical model returning an extensive and very dynamic offshore ice sheet characterized by numerous independent but connected accumulation centres from west to east above central Iceland; centres that were drained by large fast flowing outlet ice streams that penetrated well into the heart of the ice sheet delivering about $600 \mathrm{~km}^{3} \mathrm{a}^{-1}$ of ice and freshwater into the ocean around the ice sheet. The LGM ice sheet had a substantial proportion of its base (63-81\%) grounded below LGM sea-level [30], which means that that part of the ice sheet was marine-based and thus sensitive to sealevel rise and arrival of relatively warm Atlantic water eventually surrounding the ice sheet [31]. The modelled extent of a LGM IIS fairly well resembles earlier empiric attempts to reconstruct the configuration of the ice sheet [56] (Fig. 1).

The IIS LGM has not yet been dated, as sediment cores retrieved from the shelf west and north off Iceland have provided dates that only constrain the LGM situation there. Radiocarbon dates between 29.1 and $45.7 \mathrm{ka}$ BP (Table 1, 1-2) pre-date the LGM while dates between 13.7 and $18.6 \mathrm{ka}$ BP (Table 1, 3-4) post-date it on the shelf around Iceland [3, 18, 54, 77]. On the Reykjanes peninsula in Southwest Iceland, basal till carrying fossiliferous sediment clasts have yielded an age of about $28.2 \mathrm{ka} \mathrm{BP}$ (Table 1,5). Six more samples have returned ages between 24.4 and $27.7 \mathrm{ka} \mathrm{BP}$ (Table 1, 6-7), pre-dating a glacier advance towards an LGM position west off Southwest Iceland [54]. The LGM situation was, thus, most likely reached sometime between 24.4 and $18.6 \mathrm{ka} \mathrm{BP}$.

The onset of deglaciation of the Iceland shelf most likely occurred at about or a little later than $18.6 \mathrm{ka} \mathrm{BP}$ - the oldest radiocarbon date post-dating the LGM on the shelf [54]. Foraminiferal assemblages and radiocarbon dates from a sediment core retrieved from the shelf off North Iceland show that relative warm Irminger sea-water had reached that area no later than $16.3 \mathrm{ka} \mathrm{BP}$ and that at about $15.7 \mathrm{ka} \mathrm{BP}$ (Table 1,8-9) the strength of the palaeo-Irmingar Current was reduced and relatively cold water-masses characterized the environment until early Holocene times [18]. Off West Iceland both sediments and foraminiferal assemblages, dated to about $15.0 \mathrm{ka} \mathrm{BP}$ (Table 1,10) indicate ice-distal conditions and immigrations of slope species onto the shelf there in association with relative warm Irminger sea-water 


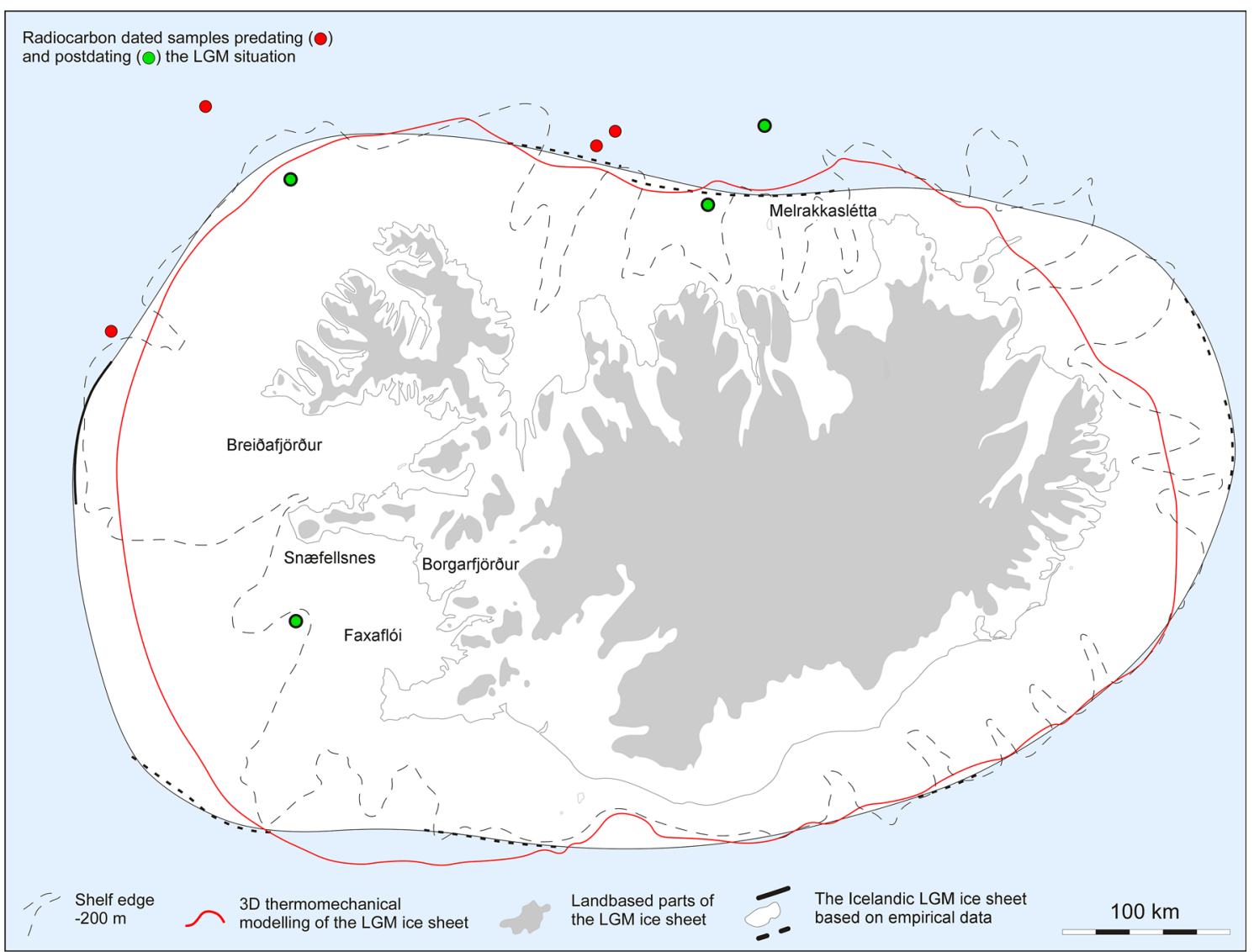

Fig. 1 Ostensible LGM extent of the Icelandic ice sheet based on moraines and other physical evidence on the Iceland shelf. The modelled outline and land-based portion of the ice sheet are according to Hubbard et al. [31]. Modified after Norðdahl and Pétursson [54]

[40]. Series of radiocarbon dates from a sediment core retrieved from the shelf off West Iceland [40], with a basal date of about $15.0 \mathrm{ka} \mathrm{BP}$, have produced an age-depth model returning an age of about $15.6 \mathrm{ka} \mathrm{BP}$ for the earliest deglaciation and onset of deposition of marine sediments there [54]. Considering the general pattern of ocean currents and circulation around Iceland [81] it is evident that when warm sea-water reached the waters off North Iceland it was already west off Iceland and probably all around the island.

Subsequently to the arrival of warm Atlantic sea-water around Iceland the ice sheet started to retreat and according to radiocarbon dated marine shells from the Melrakkaslétta peninsula in Northeast Iceland (Fig. 1), ML shorelines at 50-60 m a.s.l. were formed at about $14.8 \mathrm{ka}$ BP (Table 1, 11) and at that time the shelf off Northeast Iceland must have been ice free [54, 62]. In West Iceland, marine shells and a whalebone have yielded dates for two broadly synchronous ML shorelines at about 150 and $105 \mathrm{~m}$ a.s.l, respectively, some $20 \mathrm{~km}$ apart. At Stóri-Sandhóll and Stóra-Fellsöxl, shells and whalebone, respectively, date the ML to about $14.7 \mathrm{ka}$ BP (Table 1, 12-15) [36]. Lloyd et al. [49] attributed an age of about $14.1 \mathrm{ka} \mathrm{BP}$ (Table 1,16) to a ML shoreline at about $80 \mathrm{~m}$ a.s.l. in Northwest Iceland.
Formation of these highly elevated ML shorelines show that when the shorelines were formed there prevailed a temporal equilibrium between the rate of glacio-isostatic uplift and that of RESL rise.

By comparing the time for onset of initial deglaciation of the Iceland shelf to the age of ML shorelines, the shelf areas seem to have been totally deglaciated during a time span of about 300 years (between 15.0 and $14.7 \mathrm{ka} \mathrm{BP}$ ). Syvitski et al. [77] suggested that the dominant ablation mode was calving rather than melting. During this time RESL was continuously rising [21, 45, 46]. Ingólfsson and Norðdahl [36] tentatively suggested that floating and destabilization of the marine based part of the IIS led to its collapse and rapid disappearance from the shelf around Iceland. Following a temporal near glacio-isostatic equilibrium and formation of ML shorelines at about $14.7 \mathrm{ka}$ $\mathrm{BP}$, the IIS reacted to an ongoing climatic improvement, melted and retreated into the interior parts of Iceland. Estimated age of subareal lava flows and lava capped tuyas in Northeast Iceland $[48,78]$ indicate that the IIS had been reduced to about $25-20 \%$ of its LGM-size at about $13.8 \mathrm{ka}$ BP $[55,56]$. The relative sea level (RSL) history of Iceland is fairly well known, and constrained by numerous ${ }^{14} \mathrm{C}$ 
Table 1 Radiocarbon dated samples referred to in this paper with references to their original publication

\begin{tabular}{|c|c|c|c|c|c|c|c|}
\hline & Lab code & Sample & Age ${ }^{14} \mathrm{C}$ BP & $\begin{array}{l}\text { Cal age range } \\
\text { BP 95.4\% }( \pm 2 \sigma)\end{array}$ & $\begin{array}{l}\text { Age ka } \\
\text { BP }\end{array}$ & $\begin{array}{l}\text { Calibration } \\
\text { dataset }\end{array}$ & References \\
\hline 1 & CAMS-27763 & 97-323PC1, $292 \mathrm{~cm}$ & $25.330 \pm 640$ & $27.776-30.457$ & 29.1 & Marine 13 & {$[3]$} \\
\hline 2 & AAR-3887 & $97-322 \mathrm{PC}, 161 \mathrm{~cm}$ & $42.600 \pm 3050$ & $41.332-50.000$ & 45.7 & Marine 13 & [3] \\
\hline 3 & AAR-4209 & $97-317 \mathrm{PC}, \geq 245 \mathrm{~cm}$ & $12.270 \pm 100$ & $13.454-13.947$ & 13.7 & Marine 13 & {$[3]$} \\
\hline 4 & CAMS-46527 & 96-1234GGC, $259 \mathrm{~cm}$ & $15.720 \pm 70$ & $18.373-18.735$ & 18.6 & Marine 13 & {$[3]$} \\
\hline 5 & AAR-2803 & Sandgerði (maximum pre-LGM date) & $24.510 \pm 200$ & $27.751-28.567$ & 28.2 & Marine 13 & [41] \\
\hline 6 & Beta-82638 & Njaðvíkurheiði (minimum pre-LGM date) & $20.630 \pm 340$ & $23.516-25.235$ & 24.4 & Marine 13 & [41] \\
\hline 7 & AAR-2577 & Njaðvíkurheiði & $23.980 \pm 230$ & $27.338-28.094$ & 27.7 & Marine 13 & [41] \\
\hline 8 & AAR-3383 & HM107-05, 393.0-394.3 cm & $13.980 \pm 90$ & $16.038-16.650$ & 16.3 & Marine 13 & {$[18]$} \\
\hline 9 & AAR-4115 & HM107-05, 364-366 cm & $13.560 \pm 90$ & $15.389-16.054$ & 15.7 & Marine 13 & {$[18]$} \\
\hline 10 & AA-12896 & 193030-006LCF $1235 \mathrm{~cm}$ & $13.105 \pm 85$ & $14.652-15.368$ & 15.0 & Marine 13 & {$[40]$} \\
\hline 11 & T-4468 & Hvalvík (marine limit at $>50 \mathrm{~m}$ a.s.1.) & $13.020 \pm 90$ & $14.363-15.236$ & 14.8 & Marine 13 & {$[62]$} \\
\hline 12 & Ua-21222 & Stóri-Sandhóll (marine limit at $150 \mathrm{~m}$ a.s.l.) & $12.975 \pm 105$ & $14.252-15.185$ & 14.8 & Marine 13 & {$[36]$} \\
\hline 13 & Ua-12021 & Stóri-Sandhóll (marine limit at $150 \mathrm{~m}$ a.s.l.) & $12.880 \pm 85$ & $14.181-15.042$ & 14.6 & Marine 13 & {$[36]$} \\
\hline 14 & AAR-3734 & Stóra-Fellsöxl (marine limit at $105 \mathrm{~m}$ a.s.l.) & $12.940 \pm 80$ & $14.268-15.111$ & 14.7 & Marine 13 & {$[50]$} \\
\hline 15 & Mean & Stóri-Sandhóll/Stóra-Fellsöxl (marine limit) & $12.918 \pm 68$ & $14.301-15.064$ & 14.7 & Marine 13 & \\
\hline 16 & Estimate & Hríshóll 1 & $12.185 \pm 100$ & $13.759-14.505$ & 14.1 & Intcal 13 & [49] \\
\hline 17 & Lu-2195 & Ásbakkar & $12.870 \pm 110$ & $14.139-15.073$ & 14.6 & Marine 13 & [34] \\
\hline 18 & Lu-2339 & Gröf & $12.840 \pm 110$ & $14.107-15.043$ & 14.5 & Marine 13 & {$[35]$} \\
\hline 19 & Lu-2193 & Melaleiti & $12.830 \pm 110$ & $14.095-15.032$ & 14.5 & Marine 13 & {$[34]$} \\
\hline 20 & Lu-2194 & Grjóteyri & $12.830 \pm 110$ & $14.095-15.032$ & 14.5 & Marine 13 & {$[35]$} \\
\hline 21 & Lu-2371 & Árdalsá & $12.510 \pm 140$ & $13.576-14.495$ & 14.0 & Marine 13 & {$[35]$} \\
\hline 22 & Lu-2055 & Laxá & $12.470 \pm 110$ & $13.640-14.193$ & 13.9 & Marine 13 & {$[35]$} \\
\hline 23 & Lu-2192 & Melaleiti & $12.460 \pm 120$ & $13.590-14.206$ & 13.9 & Marine 13 & {$[34]$} \\
\hline 24 & Lu-2379 & Ás & $12.380 \pm 110$ & $13.539-14.090$ & 13.8 & Marine 13 & {$[34]$} \\
\hline 25 & Lu-2377 & Ásbakkar 3 & $12.310 \pm 110$ & $13.473-14.011$ & 13.7 & Marine 13 & {$[34]$} \\
\hline 26 & U-0641 & Melar & $12.290 \pm 160$ & $13.386-14.084$ & 13.7 & Marine 13 & {$[35]$} \\
\hline 27 & Lu-2374 & Skipanes 2 & $12.250 \pm 100$ & $13.437-13.924$ & 13.7 & Marine 13 & {$[35]$} \\
\hline 28 & Lu-2375 & Melabakkar-Melar 2 & $12.350 \pm 120$ & $13.493-14.071$ & 13.8 & Marine 13 & {$[34]$} \\
\hline 29 & Lu-2376 & Ásbakkar 2 & $11.830 \pm 100$ & $13.077-13.481$ & 13.3 & Marine 13 & {$[34]$} \\
\hline 30 & Lu-2373 & Ásbakka-Ásgil 3 & $11.910 \pm 140$ & $13.075-13.678$ & 13.4 & Marine 13 & [34] \\
\hline 31 & Lu-2196 & Ásbakkar-Ásgil 1 & $11.980 \pm 130$ & $13.163-13.716$ & 13.4 & Marine 13 & [34] \\
\hline 32 & Lu-2372 & Ásbakkar-Ásgil 2 & $12.080 \pm 120$ & $13.277-13.790$ & 13.5 & Marine 13 & {$[34]$} \\
\hline
\end{tabular}

All the dates have been reservoir corrected by $365 \pm 20{ }^{14} \mathrm{C}$ years $[\Delta R=24 \pm 23]$, the apparent age for living marine organisms around Iceland [27]. Calibrated ages are obtained with the Radiocarbon Calibration Program (CALIB) Rev. 7.1 [76]; terrestrial material with the data set Intcal 13 [67] and marine material with the data set Marine 13 [67]. Weighted mean age and standard deviation of dated samples are also calculated with CALIB Rev. 7.0.4 [76]

dates (Fig. 2). It reveals exceptionally rapid isostatic responses to changes in glacial loading and unloading during the deglaciation of Iceland.

\section{Materials and methods}

The highly elevated ML shorelines formed during the early stages of the last deglaciation of Iceland and the early Holocene depletion of glacio-isostatic uplift [54, 72] bear witness to highly sensitive interaction between changes in loading and unloading of the crust, physical properties of the crust (lithosphere) and the asthenosphere underneath Iceland. Below, we account for some of these properties and factors controlling the rate of glacio-isostatic uplift and subsidence of the crust and what has controlled the rate of changes in the mass balance of the IIS during its last deglaciation, i.e., changes in loading and unloading of the crust.

\section{Lithospheric and asthenospheric properties below Iceland}

Vertical crustal deformation-isostatic uplift and subsidence-is known to have progressed at very high rates in 
Fig. 2 Development of RSL changes based on data from West Iceland. Modified from Ingólfsson et al. [37], Norðdahl and Pétursson [54], Norðdahl et al. [56] and Pétursson et al. [63]

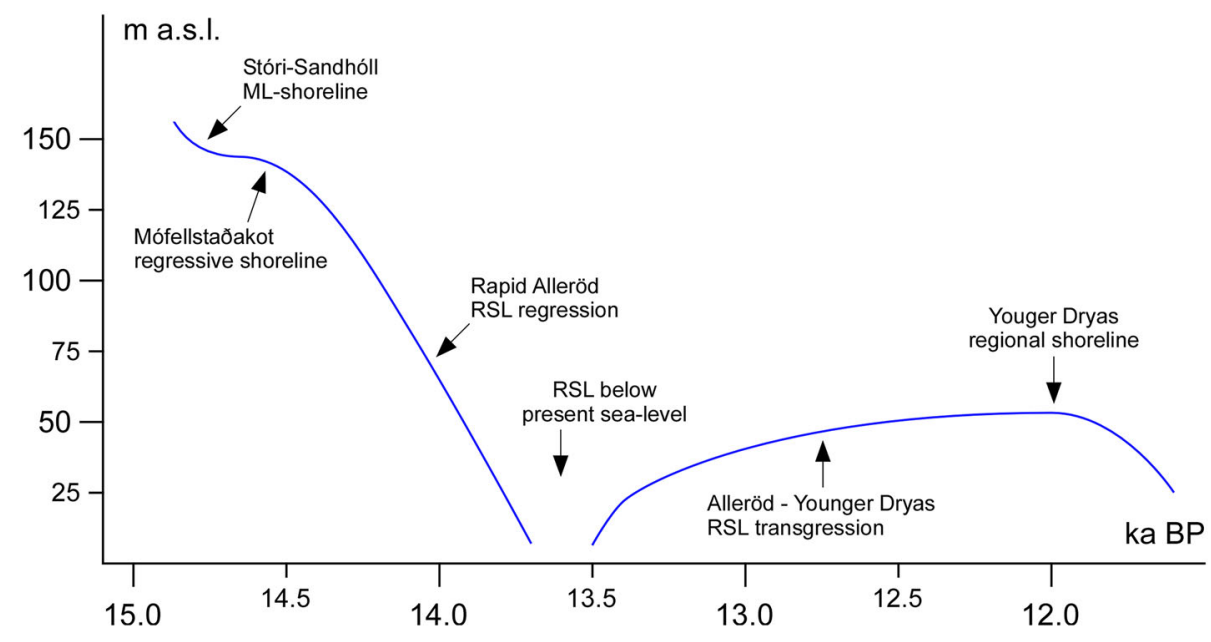

Iceland because asthenospheric material could readily flow from or towards a centre of loading and unloading [72], Ingólfsson and Norðdahl [36, 54]. Rates of glacio-isostatic uplift and subsidence are controlled by the rate of loading and unloading of the crust, i.e., the mass balance of the ice sheet, and by the physical properties of the lithosphere and the asthenosphere below Iceland. Rheological structure of Iceland has been determined by seismology, and by magnetotelluric and GPS surveys that together have revealed a layered structure of the lithosphere [64]. First, there is about $4 \mathrm{~km}$ thick brittle and laterally variable upper crust underlain by about $8 \mathrm{~km}$ thick elastic lower crust, and then another about $8 \mathrm{~km}$ thick ductile and laterally more uniform layer [22, 64]. The asthenosphere below Iceland is about $200 \mathrm{~km}$ thick with relatively low viscosity that enables it to flow at high velocities (e.g. [4, 22, 73]). High rates of glacio-isostatic adjustments in Iceland are, therefore, explained by rapid deglaciation, thickness and physical properties of the lowermost crust possibly with high fraction of partial melt [64], and viscosity of plastically deformable asthenosphere, or thickness of the crust. Bjarnason and Schmeling [6] have shown that both crust and lithosphere are thinner in West Iceland compared with e.g. Northwest and East Iceland. Different altitudes of ML shorelines in these parts of Iceland could possibly be explained by these differences in crustal structure.

Previous glacio-isostatic studies and modelling have returned asthenospheric viscosity estimates of $1-2 \times 10^{18}$ Pa s [22], 4-10 × $10^{18} \mathrm{~Pa} \mathrm{~s}$ [58], and $1 \times 10^{19} \mathrm{~Pa} \mathrm{~s}$ [4]below a 10-30 km thick elastic lithosphere. Pagli et al. [58] reported recent uplift rates in reaction to the ongoing thinning of Icelandic glaciers between +9 and $+25 \mathrm{~mm}$ $\mathrm{a}^{-1}$ and Árnadóttir et al. [4] as high as $+23 \mathrm{~mm} \mathrm{a}^{-1}$. Recently, an uplift rate of some $+35 \mathrm{~mm} \mathrm{a}^{-1}$ has been reported for northwestern Vatnajökull [15]. Viscosity values as low as $5 \times 10^{17} \mathrm{~Pa}$ s for the asthenosphere below
Vatnajökull were proposed by Sjöberg et al. [73] in order to explain discrepancies between observed and predicted uplift rate as high as $+19 \mathrm{~mm} \mathrm{a}^{-1}$. These modern uplift rates are regarded as very high compared to uplift rates in areas with different lithospheric and asthenospheric rheology. It is important in this context to underline that the very rapid deglaciation of the IIS and unloading of the crust were occurring at about the same rate, generating very high rates of uplift and flow of asthenospheric material towards the centre of uplift. Radiocarbon dated relative sea level curves and ages of ML shorelines help understanding rates of uplift during the deglaciation. In Reykjavík, Southwest Iceland, a maximum uplift rate of about $+46 \mathrm{~mm} \mathrm{a}$ occurred between 12.0 and $10.7 \mathrm{ka}$ BP [37]. In Northwest Iceland (Breiðafjörður) Lloyd et al. [49] showed that an early deglacial (Bølling-Allerød) uplift progressed at a rate of about $+56 \mathrm{~mm} \mathrm{a}^{-1}$ between 14.1 and $13.3 \mathrm{ka} \mathrm{BP}$. Early Holocene uplift rate of about $+107 \mathrm{~mm} \mathrm{a}^{-1}$ has been shown for the Skagi peninsula in North Iceland between 11.5 and 11.3 ka BP [69], and in Berufjörour, East Iceland, glacio-isostatic uplift may have progressed at rates as high as $+34 \mathrm{~mm} \mathrm{a}^{-1}$ between 12.0 and $11.2 \mathrm{ka} \mathrm{BP} \mathrm{[53].} \mathrm{The} \mathrm{yet}$ highest known rate of uplift in Iceland commenced at about $14.7 \mathrm{ka} \mathrm{BP}$ and progressed at a minimum rate of about $+159 \mathrm{~mm} \mathrm{a}^{-1}$ until about 14.0 ka BP [54].

\section{Thickness of a plastic ice sheet}

To evaluate glacio-isostatic movements of the crust in postLGM times, it is necessary to estimate the thickness of the ice sheet and the elevation of its surface at each time and location on a longitudinal profile between its edge and centre (Fig. 3). For that we have used the ice sheet returned by an Optimum LGM Experiment (OLE) of a three dimensional thermomechanical model of the LGM IIS [30, 31]. To reconstruct the LGM ice sheet we have used a best- 


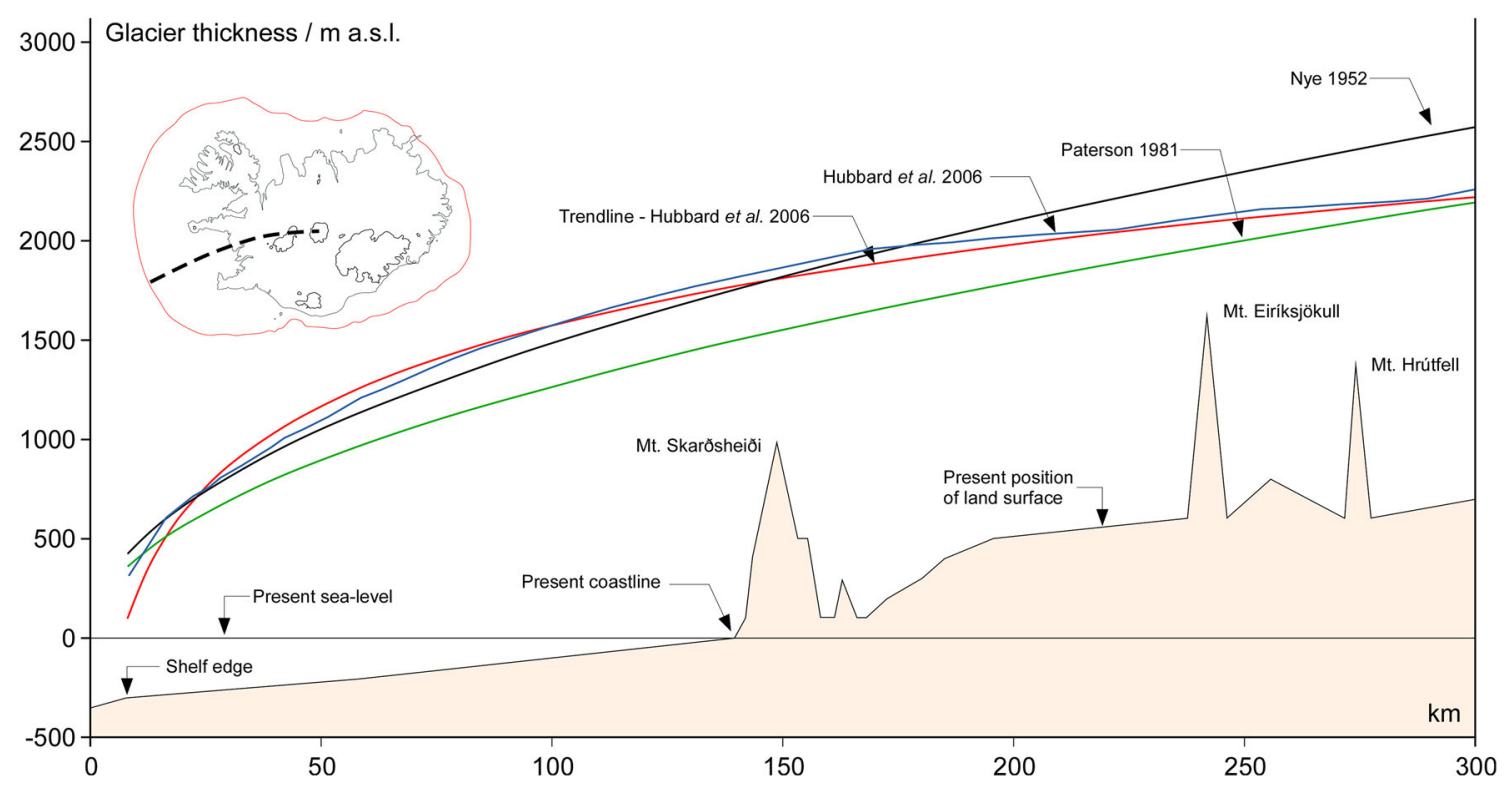

Fig. 3 A longitudinal profile (blue) for an optimum LGM Experiment (OLE) of a 3D thermomechanical model of the IIS [31] and a best-fit-curve to it (red) along a flowline above the Faxaflói bay between the Snæfellsnes and Reykjanesskagi peninsulas in Southwest Iceland (see the inserted map of Iceland). Two profiles (black and green) for a perfectly plastic ice sheet $[57,59]$ are shown for

fit-curve [logarithmic] to the modelled longitudinal profile (OLE) of the Icelandic LGM ice sheet (Fig. 3);

$h_{i}=584 \cdot \ln \left(R_{0}-r\right)-5153$

where $h_{i}$ is the glacier thickness; $R_{0}$ is the radius of the ice sheet; $r$ is the distance from centre of the ice sheet. For comparison, we have also plotted two slightly different longitudinal profiles of a perfectly plastic ice sheet (Fig. 3) but with slightly different shear stresses $\left(\tau_{0}\right)$ at the base of the ice sheet according to Paterson [59] (Eq. 2) and Nye [57] (Eq. 3). These profiles are expressed as:

$h_{i}=\sqrt{\frac{2 \tau_{0}}{\rho g}} \cdot \sqrt{R_{0}-r}=4.0 \cdot \sqrt{R_{0}-r}$

$h_{i}=\sqrt{\frac{2 \tau_{0}}{\rho g}} \cdot \sqrt{R_{0}-r}=4.7 \cdot \sqrt{R_{0}-r}$

where $h_{i}, R_{0}$ and $\mathrm{r}$ are as before; $\tau_{0}$ is the ice sheet basal shear stress; $\rho$ is the ice density; $g$ is the acceleration of gravity.

\section{Glacio-isostatic uplift and equilibrium}

Our calculations of glacio-isostatic subsidence assume near isostatic equilibrium at all times during the post-LGM reduction of the ice sheet, and that equilibrium could be established in only tens of years rather than in hundreds of years. This assumption is, e.g., supported by comparison with the profile from Hubbard et al. [31]. The modern landscape along this profile is obtained from a topographic map $(1: 750,000)$ and it is characterized by a broad shelf continuously rising from $-350 \mathrm{~m}$ b.s.l. to about $700 \mathrm{~m}$ a.s.l. in the centre of Iceland and also by high coastal mountain (Mt. Skarðsheiði) and volcanoes (Mt. Eiríksjökull and Mt. Hrútfell) in the interior part of Iceland

Sigmundsson's [71] results. He concluded that if a $1000 \mathrm{~m}$ thick ice sheet with a radius of $160 \mathrm{~km}$ was instantly removed from a $10 \mathrm{~km}$ thick crust with $1 \times 10^{19} \mathrm{~Pa} \mathrm{~s}$ asthenosphere viscosity, the consequent glacio-isostatic uplift would be more or less depleted in little more than 400 years. For our calculations of a maximum glacio-isostatic subsidence beneath the centre of the ice sheet, we have used a simple equation (Eq. 4) from Gray [24] for the subsidence at glacio-isostatic equilibrium:

$D_{\max }=H_{i} \cdot \frac{\rho_{i}}{\rho_{\text {as }}}$

where $D_{\max }$ is glacio-isostatic subsidence; $H_{i}$ is ice thickness; $\rho_{i}$ is density of ice and $\rho_{\text {as }}$ is asthenosphere density (3.370 $\mathrm{Mg} \mathrm{m}^{-3}$, [38]). To calculate the glacio-isostatic subsidence at the edge of the ice sheet we have used an equation (Eq. 5) from Walcott [82] in Gray [24]:

$W_{d}=\frac{2 H \rho_{i}}{10\left(\rho_{\text {as }}-\rho_{i}\right)}=\frac{H}{13.4}$

where $W_{d}$ is depression at the ice margin; $H$ is maximum surface elevation for a given ice sheet; $\rho_{i}$ and $\rho_{\text {as }}$ as before.

\section{Eustasy-glacier volume and relative eustatic sea-level}

The major cause of sea-level change over interglacialglacial cycles is the exchange of water between ice and ocean and the crust's dynamic response to the changing 
surface load [46], and during LGM ice volume maximum, RESL was some 120-130 m lower than today [21, 45, 61]. This lowering was equal to ice volume equivalent sea level as low as -140 to $-134 \mathrm{~m}[45,46]$. The time and duration of the LGM (ice volume maximum) have been defined from about $29.0 \mathrm{ka}$ BP and until about $21.0 \mathrm{ka}$ BP when land-based glaciers started melting [13, 45, 46]. Between 16.5 and $8.2 \mathrm{ka}$ BP RESL rose at an average rate of about $+12.0 \mathrm{~mm} \mathrm{a}^{-1}$ [46]. Mwp-1A (e.g. [8, 12, 21, 45, 46, 60]) is now understood to have started at about $14.5 \mathrm{ka} \mathrm{BP}$ and ended at about $14.0 \mathrm{ka} \mathrm{BP}$ with a maximum rate of RESL rise as high as $+46.0 \mathrm{~mm} \mathrm{a}^{-1}[16,46]$. In Younger Dryas times, between 12.5 and $11.5 \mathrm{ka} \mathrm{BP}$, the rate of RESL rise was temporarily reduced. From 8.2 to about $2.5 \mathrm{ka}$ BP ocean sea level rose at progressively reduced rate and reached its present position [46]. The approximate position of RESL is needed when evaluating the rate of glacioisostatic adjustment during the deglaciation of Iceland, and the position of RESL at different occasions is determined by rates of RESL rise according to Lambeck et al. [45] at different times during the Late Weichselian.

\section{Relative sea-level changes and formation of ML shorelines}

Relative sea level is controlled by RESL and glacio-isostasy at given times and places, and for shorelines to be formed, littoral and sublittoral sediments to be accumulated, and marine organism to settle and thrive in such an environment, the rate of eustatic change has to be equal to the rate glacio-isostatic uplift, meaning that the rate of RSL change becomes equal to zero for a period of time. Rates of RESL changes were always positive with rising sea-level throughout the deglaciation. Both temporal and spacial variations in glacio-isostatic uplift rates were much greater and generally positive (uplifting) but locally and temporarily negative with subsiding crust. Together these two components-rates of RESL change and rates of glacioisostatic uplift-determined highly variable rates of RSL change. This relationship can be express as:

$R_{\mathrm{RSL}}=R_{\mathrm{Eu}}-R_{\mathrm{Up}}=\frac{\delta\left(h_{\mathrm{Eu}}\right)-\delta\left(h_{\mathrm{Up}}\right)}{-\delta(t)}$

where $R_{\mathrm{RSL}}$ is the rate of relative sea-level change, $R_{\mathrm{EU}}$ is the rate of relative eustatic sea-level change, $R_{\mathrm{Up}}$ is rate of glacio-isostatic uplift, $h_{\mathrm{Eu}}$ and $h_{\mathrm{Up}}$ are the vertical positions of RESL and raised shorelines at times $t_{1}$ and $t_{2}$. Solving this equation for different rates of RESL rise and glacioisostatic uplift yields three principal results where:

If $\quad R_{\mathrm{RSL}}<0 \rightarrow R_{\mathrm{Up}}>R_{\mathrm{Eu}}$

Then we have regression of RSL

If $\quad R_{\mathrm{RSL}} \sim 0 \rightarrow R_{\mathrm{Up}} \sim R_{\mathrm{Eu}}$

Then we have formation of a shoreline

If $\quad R_{\mathrm{RSL}}>0 \rightarrow R_{\mathrm{Up}}<R_{\mathrm{Eu}}$

Then we have transgression of RSL

These different results for rate of $R_{\mathrm{RSL}}$ can also be expressed graphically and of special interest is the situation when $R_{\mathrm{Up}}$ is close or equal to $R_{\mathrm{Eu}}$ (Eq. 6b), i.e., when extensive shorelines were formed and temporarily the rate of RSL change was close or equal to zero (Fig. 4). Such plateaus $\left(R_{\mathrm{RSL}} \sim 0\right)$ occurred when the rate of glacioisostatic uplift was decreased to such a degree that it was about the same as the rate of RESL rise. There are basically three possible ways for such a situation to occur (Fig. 4): Firstly, during a period of an ongoing regression of RSL $\left(R_{\mathrm{RSL}}<0\right)$, rate of glacio-isostatic uplift was considerably
Fig. 4 A conceptual diagram for relative sea-level (RSL) changes emphasizes that shorelines are more likely to be formed when the rate of glacioisostatic uplift is about equal to the rate of RESL rise, i.e., when the rate of RSL change is equal to zero. Such a situation arises when (1) an ongoing rate of glacio-isostatic uplift is reduced to equal the rate of RESL rise, (2) when the rate of positive glacio-isostatic uplift becomes negative, and (3) when the rate of negative glacio-isostatic uplift becomes positive

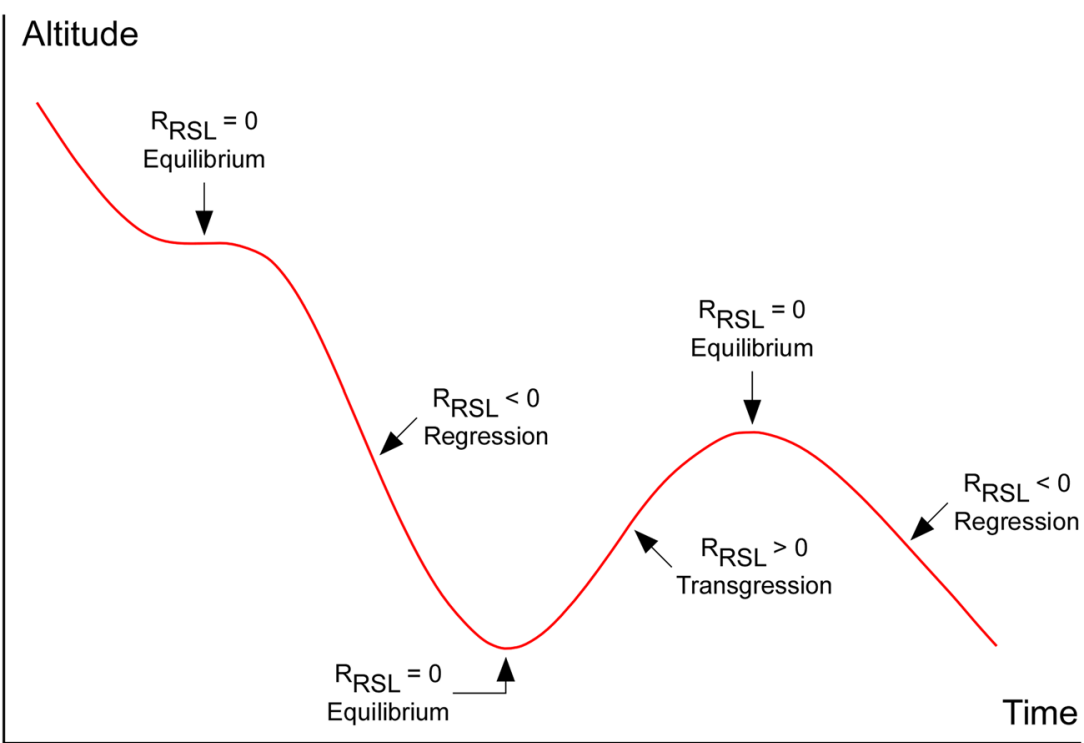


but temporarily reduced to equal the rate of RESL rise $\left(R_{\mathrm{RSL}} \sim 0\right)$. For that to occur glacier load on the local crust must have been stable (unchanged), i.e., an isostatic equilibrium prevailed for a period of time. Regression of RSL was resumed when glacier load on the crust was again reduced because of negative mass balance and retreat of the glaciers. Secondly, when glacio-isostatic equilibrium was reached due to stabilization of the glacier load which reduced the rate of glacio-isostatic uplift to equal to the rate of RESL rise, which again changed the rate of RSL change to a value close to zero $\left(R_{\mathrm{RSL}} \sim 0\right)($ Fig. 4$)$. A subsequent transgression of RSL $\left(R_{\mathrm{RSL}}<0\right)$ could only occur through inversion of glacio-isostasy, i.e., when an ongoing uplift of the crust was reversed into subsidence caused by increased glacier loading on the crust due to positive mass balance and advance of the glaciers. Thirdly, when an isostatic equilibrium was reached, following a period of glacioisostatic subsidence due to glacier growth and increased loading on the crust, an ongoing transgression of RSL $\left(R_{\mathrm{RSL}}>0\right)$ was temporarily brought to a halt $\left(R_{\mathrm{RSL}} \sim 0\right)$ (Fig. 4). The subsequent regression of RSL $\left(R_{\mathrm{RSL}}<0\right)$ was caused by renewed and relatively rapid glacio-isostatic uplift that in turn was caused by reduced glacier load due to negative mass-balance of the glaciers in early Holocene times (Fig. 4).

\section{Climatic development around the North Atlantic Ocean}

The NGRIP ice cores retrieved from the Greenland ice sheet have been analyzed for variations in stable oxygen isotope $\left({ }^{18} \mathrm{O} /{ }^{16} \mathrm{O}\right)$ ratios, expressed as $\delta^{18} \mathrm{O} \%$, which reflect changes in the isotopic composition of both the evaporated sea water and the precipitation up on top of the Greenland ice sheet. Changes in $\delta^{18} \mathrm{O} \%$ values in the NGRIP ice cores can be used as an indirect proxy for climatic changes and have been correlated with concurrent temperature variations in the North Atlantic Region. Here we use the $\delta^{18} \mathrm{O}$ curve from the NGRIP ice cores with the GICC05 chronology [65] as a proxy for comparing general development of North Atlantic climate with rapid changes in extent of the Icelandic ice sheet during the Late Weichselian-between 19.0 and $11.0 \mathrm{ka}$ BP (Fig. 5).

Land-based glaciers started melting about $21.0 \mathrm{ka}$ BP with a subsequent rise of RESL [46] and generally increased $\delta^{18} \mathrm{O} \%$ values for the NGRIP ice cores reflecting variable but a slow and continuous improvement of the climate until shortly after $15.0 \mathrm{ka} \mathrm{BP}$ when an abrupt rise in the $\delta^{18} \mathrm{O} \%$ values occurred and culminated at about 14.5 ka BP (Fig. 5). The initial deglaciation of the shelf off Northwest Iceland and arrival of warm sea water off North Iceland fall within this period of improved climate and with the collapse of the IIS occurring just before the onset of the Early Bølling dramatic climatic improvement at about $14.7 \mathrm{ka}$ BP. From that time onward, the $\delta^{18} \mathrm{O} \%$ values decreased during the Bølling-Allerød interstadial and reached a temporary minimum $12.6 \mathrm{ka}$ BP. The Younger Dryas cold spell is reflected by the slowly increasing $\delta^{18} \mathrm{O} \%$ values between 12.6 and $11.7 \mathrm{ka} \mathrm{BP}$ when there again was an abrupt increase in the $\delta^{18} \mathrm{O} \%$ values leading the Early Holocene climatic improvement (Fig. 5).

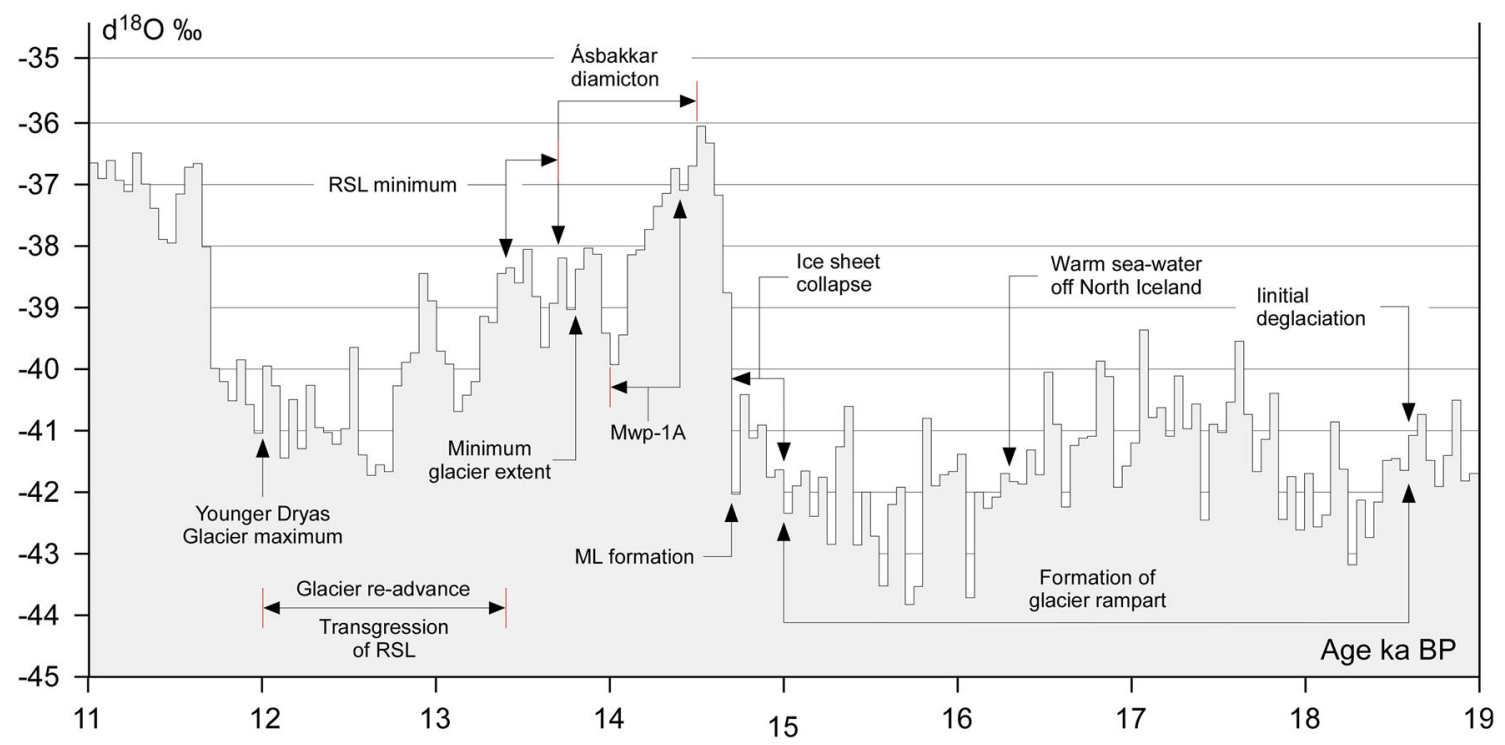

Fig. 5 Variations in stable oxygen isotope $\left({ }^{18} \mathrm{O} /{ }^{16} \mathrm{O}\right.$ ) ratios in the NGRIP ice-core (expressed as $\delta^{18} \mathrm{O} \%$ ) between 11.0 and $19.0 \mathrm{ka} \mathrm{BP}$ with the GICC05 (Greenland Ice Core Chronology 2005) chronology [65]. Important dates and events in the history of the IIS are marked on the graph 


\section{Results}

Earlier research efforts on the areal extent of the IIS have focused on describing and dating its LGM extent on the shelf (Fig. 1), its retreat from the shelf, formation of ML shorelines, and subsequent re-advances. By combining our understanding of Late Weichselian changes in the extent and thickness of the IIS with reconstruction of concurrent glacio-isostatic behavior of the Iceland crust and RESL rise we explain the collapse of the ice sheet, and how and why rapid uplift of the crust could temporarily be brought to a halt (isostatic equilibrium) allowing formation of ML shorelines and accumulation of related fossiliferous sediments.

Below, we present a conceptual two dimensional glacioisostatic equilibrium model that describes the effect of simultaneous glacio-isostatic responses to changes in glacier load on the crust and RESL changes for a few important periods (time slices) in the history of the Late Weichselian IIS along a profile above the Faxaflói bay between the Snæfellsnes and Reykjanesskagi peninsulas in Southwest Iceland, from the edge of the Iceland shelf to the interior of the island (Fig. 3). The high coastal mountain Mt. Skarðsheiði (1000 m) and two high interior mountains, Mt. Eiríksjökull (1675 m a.s.l.) and Mt. Hrútfell (1400 m a.s.l.) (Fig. 3) were covered by the LGM ice sheet and the profile demonstrates the considerable effect of glacio-isostatic subsidence during the LGM.

\section{The LGM (24.4-18.6 ka BP)}

Radiocarbon dates from the Iceland shelf and the Reykjanes peninsula constrain the duration of the maximum extent of the IIS to a period of some 6000 years, between 24.3 and $18.6 \mathrm{ka} \mathrm{BP}$, which compares well with a Northern Hemisphere LGM ice volume maximum [13, 45]. The areal extent of the LGM ice sheet covering Iceland and the shelf at that time is roughly constrained by marine geological data and bathymetry (Fig. 1) but the best estimate of its thickness is obtained from Hubbard [30] and Hubbard et al. [31]. The LGM IIS had an estimated surface area of $3.29 \times 10^{5} \mathrm{~km}^{2}$ and volume of about $3.09 \times 10^{5} \mathrm{~km}^{3}$, while its average and maximum thicknesses were 940 and $>2000 \mathrm{~m}$, respectively. Longitudinal profile of the LGM ice sheet is obtained by using a best-fit-curve (Eq. 1) to the modelled OLE surface of the ice sheet (Figs. 3, 6) [31].

The load exerted onto the crust below the IIS resulted in considerable glacio-isostatic subsidence (Eqs. 4, 5); about $-165 \mathrm{~m}$ at the edge and as much as $-600 \mathrm{~m}$ below the centre of the ice sheet. Accordingly, Mt. Skarðsheiði-the high coastal mountain in West Iceland-was isostatically lowered by about $-575 \mathrm{~m}$ and covered by about $1000 \mathrm{~m}$ of ice. At LGM the interior mountains were lowered by about $-600 \mathrm{~m}$ and covered by about 700 and $1000 \mathrm{~m}$ of ice, respectively (Fig. 6). The shelf areas were also isostatically depressed, with the present-day coastline $( \pm 0 \mathrm{~m}$ a.s.l.) isostatically subsided by about $-570 \mathrm{~m}$, which resulted in

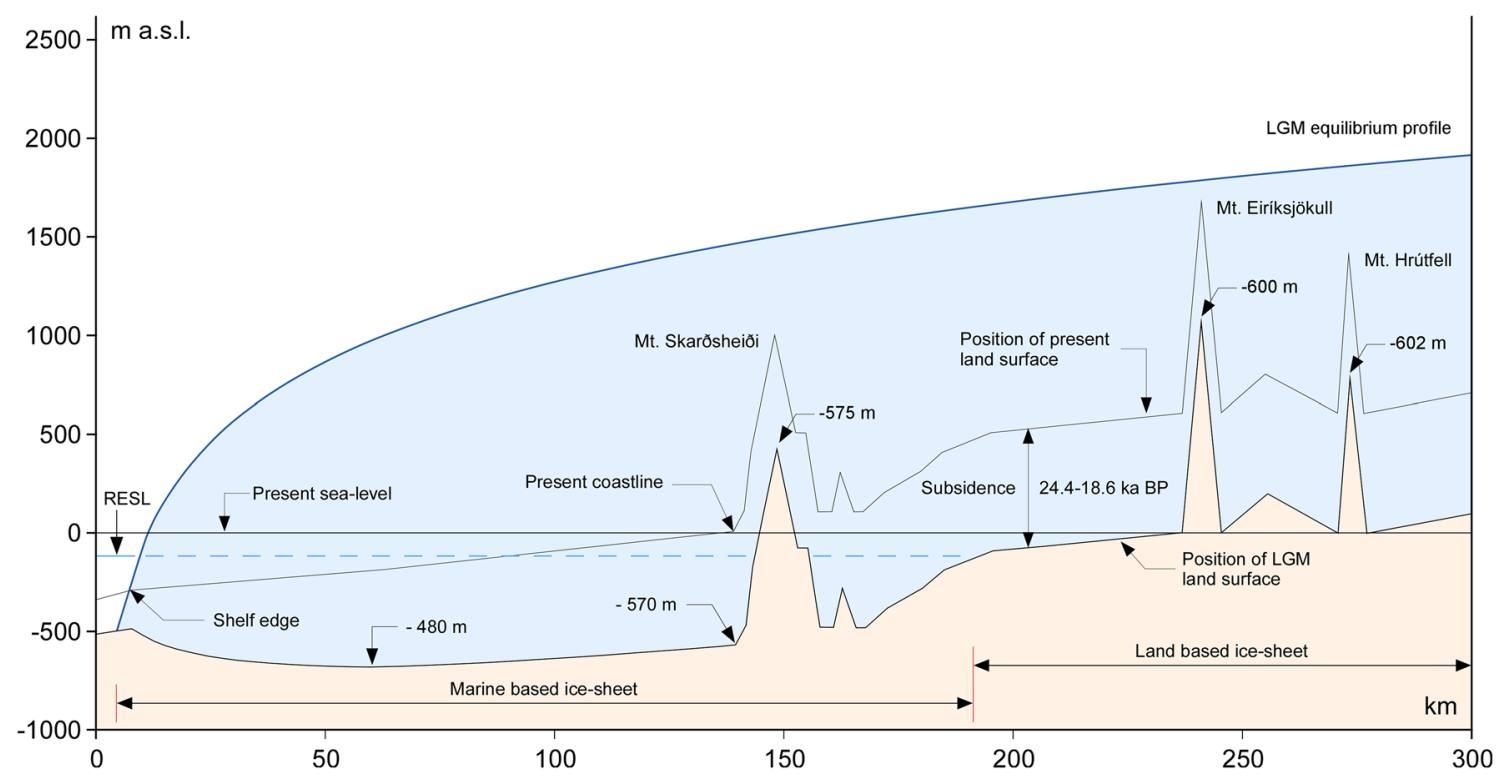

Fig. 6 The LGM (24.4-18.6 ka BP)—longitudinal equilibrium profile of the LGM ice sheet along a flow line between the edge of the shelf and the interior of West Iceland, based on a best-fit-curve (Fig. 3) to the modelled OLE surface of the ice sheet [31], with the surface of the crust lowered to a glacio-isostatic equilibrium. During LGM the glacio-isostatic subsidence was about $-165 \mathrm{~m}$ at the edge of the ice sheet, $-480 \mathrm{~m}$ in the centre of the shelf, and $-570 \mathrm{~m}$ at the present-day coastline. At the same time the interior was subsided by about $-600 \mathrm{~m}$. With RESL some $-125 \mathrm{~m}$ below present sea level, about $65 \%$ of the Icelandic ice sheet was marine based in West Iceland 
a shelf with its deepest part little less than halfway between the edge of the shelf and Mt. Skarðsheiði, causing an upgradient flow of the basal part of the LGM ice sheet there (Fig. 6). Since the IIS at LGM was crossing a retrograde bedrock slope on the shelf, it was susceptible to the marine ice sheet instability mechanisms as grounding lines can be unstable on reverse bed slopes [20, 26, 70, 83]. This probably contributed significantly to reduced ice-bed coupling, grounding line retreat and calving once deglaciation set in.

The LGM position of RESL is generally considered to have been about 120-130 m lower than the present sea level, when hydro-isostatic variations have been taken into consideration [21, 45, 61]. Here we keep the LGM sealevel at $-125 \mathrm{~m}$ b.s.l. until the beginning of RESL rise at $21.0 \mathrm{ka}$ BP which produces relative water depths between 360 and $550 \mathrm{~m}$ on the shelf off West Iceland (Fig. 6). The OLE experiment [30, 31] produced an ice sheet where substantial proportion $(\sim 63 \%)$ of it was grounded below LGM sea-level (Figs. 1, 6); thus, it was most likely sensitive to changes in the marine environment such as sudden sea-level rises (meltwater pulses) and increased sea water temperatures. A radiocarbon dated basal sample from a sediment core retrieved from the shelf off Northwest Iceland [3] indicates that at about $18.6 \mathrm{ka} \mathrm{BP}$ the Icelandic LGM ice sheet had started retreating from that part of the shelf.

\section{The collapse (15.0-14.7 ka BP)}

The shelf off West Iceland was rapidly deglaciated during a period of about 300 years [36], between about $15.0 \mathrm{ka} \mathrm{BP}$, when the Icelandic ice sheet retreated from Jökuldjúp [40] and about 14.7 ka BP, when the ML shoreline was formed at the Stóri-Sandhóll locality in West Iceland [36] (Fig. 7). The deglaciation was so sudden that it is best described as a collapse of the marginal parts of the ice sheet. The IIS had already started retreating off Northwest Iceland at about $18.6 \mathrm{ka} \mathrm{BP}$ [3], and between this initial retreat and the collapse of the marine portion at about $15.0 \mathrm{ka} \mathrm{BP}$ the mass-balance of the ice sheet must have been changed from near equilibrium (LGM) to clearly negative with considerable loss of ice mass, probably through calving [77].

This change in mass-balance probably was broadly controlled by warming of the climate and the ocean. The overall climatic development in the North Atlantic Region between about 18.6 and $15.0 \mathrm{ks} \mathrm{BP}$ is reflected in low and variable but slowly increasing $\delta^{18} \mathrm{O}$ values in the NGRIP ice core (Fig. 5), indicating rather cold and harsh but slowly improving climatic conditions up to the time of the collapse of the IIS. A somewhat more sudden and possibly more dramatic impact on the marine environment around the IIS occurred at about $16.3 \mathrm{ka} \mathrm{BP}$, when relatively warm Irminger sea water suddenly reached the shelf off North Iceland [18] (Fig. 5). Considering present ocean-current

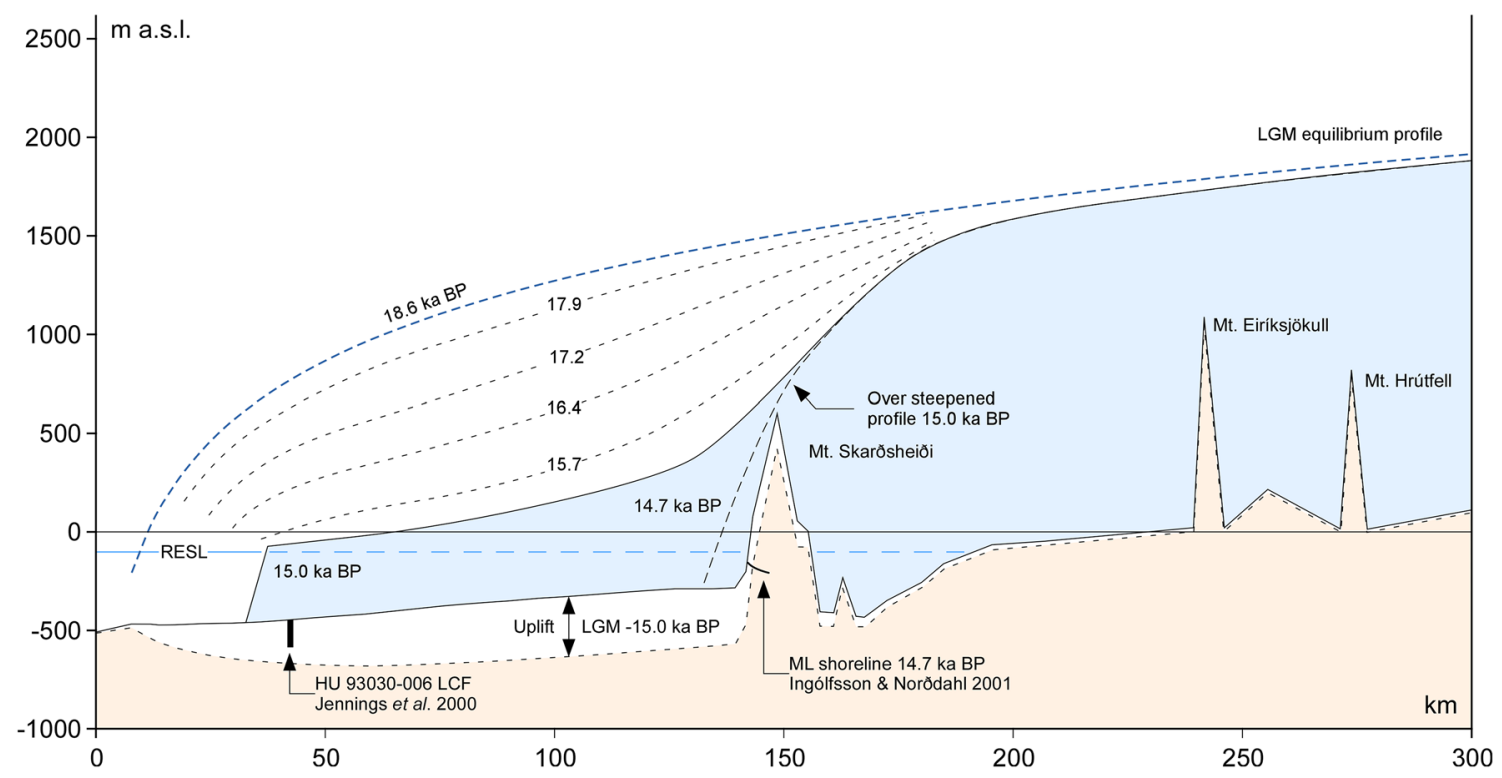

Fig. 7 The collapse (15.0-14.7 ka BP) - a marine based but grounded glacier rampart formed during continuous ablation and thinning of the ice sheet between 18.6 and $15.0 \mathrm{ka}$ BP changing the LGM equilibrium profile into a distinctive concave surface profile. The thinning of the ice sheet caused a considerable glacio-isostatic uplift of the crust below the glacier rampart, preventing it from being turned into a floating ice shelf. At the time of collapse the coastal mountain Mt. Skarðsheiði may have protruded up through the glacier surface. The HU 93030-006 LCF core [40] on the outer shelf and the Stóri-Sandhóll ML locality [36], about $100 \mathrm{~km}$ apart, were deglaciated during a period of about 300 years. At that moment and according to a 2D glacio-isostatic equilibrium model the ML shoreline in Stóri-Sandhóll was just about on height with RESL 
configuration around Iceland, Irminger sea water must have reached the shelf area off West Iceland at about $16.3 \mathrm{ka}$ BP. Between 18.6 and $15.0 \mathrm{ka} \mathrm{BP}$, RESL rose by about $22 \mathrm{~m}$, at an average rate of about $+6.3 \mathrm{~mm} \mathrm{a}^{-1}$. About $2 / 3$ of the RESL rise occurred during the last $1 / 4$ of the time, between 16.0 and $15.0 \mathrm{ka} \mathrm{BP}$, at an average rate of about $+15.0 \mathrm{~mm} \mathrm{a}^{-1}$. This high rate of RESL rise, thus, occurred just before the onset of the Mwp-1A at about $14.5 \mathrm{ka}$ BP $[16,44,46]$.

For the IIS to collapse, i.e., to disappear more or less simultaneously from the shelf and coastal parts of West Iceland, it could not undergo a normal frontal retreat (ablation) preserving the parabolic form of an equilibrium longitudinal surface profile. Instead, the ablation (deglaciation) must have changed the parabolic surface profile towards, and subsequently into, a distinctive concave surface profile of a grounded glacier rampart and an over-steepened ice stream behind it (Fig. 7). Such an extensive draw down of the marginal part of the IIS must have increased the flow-velocity of an already fast flowing ice stream [31], such as the one draining western parts of the IIS along Faxaflói, across coring site for 93030 LCF [40] in Jökuldjúp close to the edge of the shelf there, more than $100 \mathrm{~km}$ west off the Stóri-Sandhóll ML locality (Fig. 7). Hubbard [30] pointed out that the marine based ice sheet was very sensitive to sea-level changes and he also emphasized the importance of marginal processes that probably accounted for the best part of the mass wasting, notably by intensive calving at the margin of the ice sheet. During its 3600 years of initial deglaciation and formation of a grounded glacier rampart the IIS delivered about $600 \mathrm{~km}^{3} \mathrm{a}^{-1}$ of ice and freshwater into the North Atlantic Ocean [31]. Between 18.6 and 15.0 ka BP flow of ice and freshwater from the Icelandic ice sheet was temporarily increased on an average by about $20 \mathrm{~km}^{3} \mathrm{a}^{-1}$. The thinning of the parabolic ice sheet successively produced about $400 \mathrm{~m}$ thick glacier rampart that was grounded in about $350 \mathrm{~m}$ deep water when the crust below the rampart was at glacio-isostatic equilibrium with the ice load produced by the glacier rampart (Fig. 7). Although calving most likely was the dominant ablation mode, calving or floatation of the glacier rampart could not occur unless it became even thinner. The existence of such a glacier rampart at the western margin of the IIS explains how the Jökuldjúp coring site and the Stóri-Sandhóll ML locality could remain ice covered until about $15.0 \mathrm{ka} \mathrm{BP}$, when the glacier rampart collapsed and these two locations became ice free during a period of about 300 years.

At the beginning of the collapse the thickness of the glacier rampart (Fig. 7) must have been reduced to such a degree that the effectiveness of its hydrostatic pressure barrier [7, 51, 68] was severely reduced and eventually breached allowing sea water to penetrate between the base of the glacier rampart and the sea floor, hence floating the rampart and transforming it into a calving ice shelf. At that stage, the marginal part of the IIS was more receptive than before to increased rate of RESL rise and increased temperature of sea water reaching the margin of the ice sheet and accelerating its rate of ablation. Ultimately, we suggest that these environmental changes caused the collapse of the marine based marginal part of the IIS and its swift removal from the shelf area between 15.0 and $14.7 \mathrm{ka} \mathrm{BP}$. A 2D glacio-isostatic equilibrium model for such an over-steepened ice sheet produces a situation of a glacio-isostatic equilibrium for the underlying crust with the Stori-Sandhóll ML locality just below the RESL at that time (Fig. 7). It has been argued [36] that the collapse of the IIS was driven by rising RESL. Given the standard error of radiocarbon dates, Mwp-1A occurring between 14.5 and $14.0 \mathrm{ka}$ $\mathrm{BP}$ with RESL rising at a rate as high as $+46.0 \mathrm{~mm} \mathrm{a}^{-1}$ [16], and the collapse of marine based parts of the IIS roughly coincide in time. The onset of Mwp-1A coincides with the formation of the ML shoreline and accumulation of fine grained fossiliferous sublittoral sediments capped with littoral gravel sediments now reaching about $150 \mathrm{~m}$ a.s.l. and dated to about $14.7 \mathrm{ka} \mathrm{BP}$ at Stóri-Sandhóll in West Iceland [36] (Figs. 2, 5).

\section{The early Bølling Marine Limit (14.8-14.5 ka BP)}

The $150 \mathrm{~m}$ ML shoreline at Stóri-Sandhóll was formed when the IIS retreated across and eventually behind the present coastline in West Iceland. Two samples of more or less intact individuals of Balanus ssp. collected from the sublittoral sediments in Stóri-Sandhóll have returned an average age of about $14.7 \mathrm{ka} \mathrm{BP}$ for the formation of the ML shoreline there [36]. A whalebone recovered from coarse grained foreset beds of a littoral delta at the east end of Mt. Akrafjall has also been dated to about $14.7 \mathrm{ka} \mathrm{BP}$. Littoral sediments at about $125 \mathrm{~m}$ a.s.l below the southern slopes of Mt. Skarðsheiði have tentatively been correlated with the dated ML shorelines at Mt. Akrafjall and StóriSandhóll [36, 50, 54]. The age of the 3 dated samples collected from these two localities is statistically the same at a $95 \%( \pm 2 \sigma)$ probability level with a weighted mean age of about $14.7 \mathrm{ka} \mathrm{BP}$ (Table 1, 15).

In the lower Borgarfjörður area, there are in total 14 radiocarbon dated samples that stratigraphically belong to a marine phase dated between 14.8 and 13.7 ka BP (Table 1, 12-14, 17-27) (Fig. 8). Six of these dates were obtained from the Ásbakkar diamicton, a glaciomarine facies association and the earliest marine phase in the area [33-35], three of the 14 samples were collected from sublittoral sediments, thus directly dating the formation of the ML shoreline and five samples were collected from marine sediments that have been correlated with the earliest Late 
Fig. 8 The age of the 14 oldest dated samples of marine shells and a whalebone from West Iceland plotted against an arbitrary $\mathrm{x}$ axis reveal two groups of ages; an older one and a younger one covering a period of about 365 and 290 years, respectively. These groups are separated by a period of some 500 years without dates. The oldest and youngest dates are bracketing the duration of an Early Bølling marine environment in West Iceland. The dates are from Ingólfsson [34, 35], Magnúsdóttir and Norðdahl [50], and Ingólfsson and Norðdahl [36]

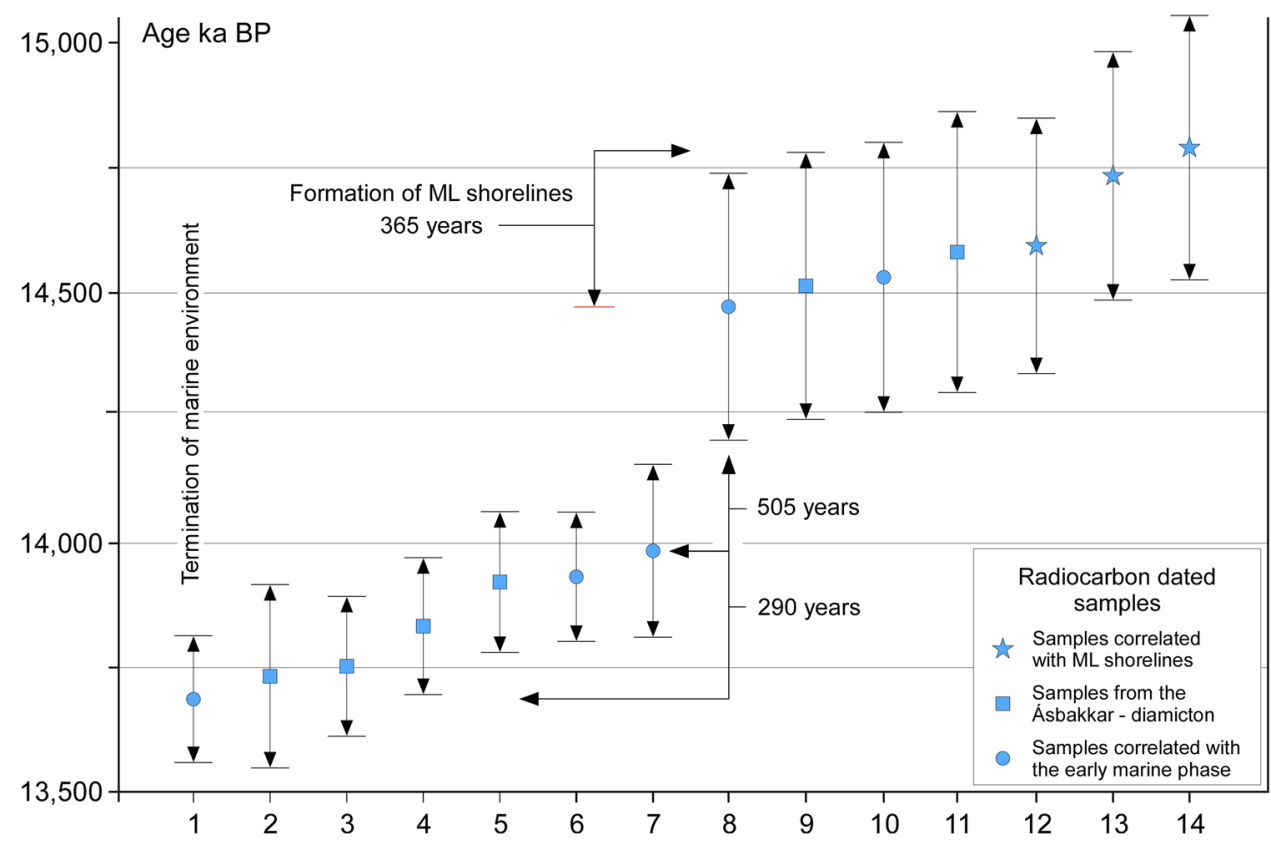

Weichselian marine phase (Fig. 8). Ordering these dates in accenting age reveals an interval with no dated samples between 14.5 and $14.0 \mathrm{ka} \mathrm{BP}$ (Fig. 8), dividing the 14 samples in two groups; a group of older samples (between 14.8 and $14.5 \mathrm{ka} \mathrm{BP}$ ) and a group of younger samples (between 14.0 and $13.7 \mathrm{ka} \mathrm{BP}$ ). The older 7 samples turn out to be statistically of the same age at a $95 \%$ probability level $( \pm 2 \sigma)$ with a weighted mean age of about $14.6 \mathrm{ka} \mathrm{BP}$, representing a period of about 365 years for the ML situation in West Iceland, while the younger samples clearly demonstrate that the early Bølling marine environment (the Ásbakkar diamicton) existed at least until about $13.7 \mathrm{ka}$ BP (Fig. 8).

For about 365 years glacio-isostatic uplift and rise of RESL must have been progressing at about the same rate, allowing formation of a shoreline in accordance with Eq. (6b) and Fig. 4. For a balanced ice sheet (Fig. 9), the 2D glacio-isostatic equilibrium model produces a situation with the Stóri-Sandhóll ML locality positively (upwardly) offset by about $90 \mathrm{~m}$, a discrepancy that supports the concept of an over-steepened ice sheet during the ML shoreline phase in West Iceland. A modelling attempt of the collapse situation (Fig. 7) returns a ML locality some $45 \mathrm{~m}$ below the RESL, a difference showing that a near equilibrium must have been prevailing between glacioisostatic uplift and rise of RESL. The Mwp-1A was at that time progressing at a rate as high as $+46 \mathrm{~mm} \mathrm{a}^{-1}$ [16] and the rate of glacio-isostatic uplift must, therefore, have been close to or equal to that rate, which is quite high when compared with present-day maximum uplift rate of about $+35 \mathrm{~mm} \mathrm{a}^{-1}$ [15] but rather low when compared with maximum Icelandic deglacial uplift rates being as high as $+159 \mathrm{~mm} \mathrm{a}^{-1}$ [54]. Such an imbalance (lagging) in glacio-isostatic uplift was most likely caused by the extremely rapid removal of the ice sheet from the shelf area while the load of an over-steepened glacier in the coastal area was reduced at much lower rate, thus hampering glacio-isostatic recovery and allowing the ML shoreline situation to prevail during a period of about 365 years.

The formation of the Stori-Sandhóll ML shoreline, the duration of the rapid Mwp-1A and the reduced rate of glacio-isostatic uplift coincides in time with the onset of the extremely swift early Bølling warming as it appears in the NGRIP $\delta^{18} \mathrm{O}$ isotope curve [65] (Fig. 5). Towards the end of this relatively short period of time, the rate of glacio-isostatic uplift must have been increased relative to the rate of RESL rise, inducing a slow relative regression of RSL and, thus, the formation of the marine terraces at levels below the $150 \mathrm{~m}$ level east of the Stóri-Sandhóll locality in West Iceland [36].

\section{A Late Weichselian minimum glacier extent (13.8 ka BP)}

The Ásbakkar diamicton [34, 35] represents the earliest Late Weichselian marine event in West Iceland. It is constrained by radiocarbon dates to the Bølling chronozone and prevailed at least until about $13.7 \mathrm{ka}$ BP when RSL regressed below present sea level. An erosional contact (hiatus) between the Ásbakkar diamicton and the Ás beds, - a succeeding lithostratigraphic unit in the Melabakkar-Ásbakkar coastal cliffs_-shows that RSL regressed at least below that contact, which is situated just a few 


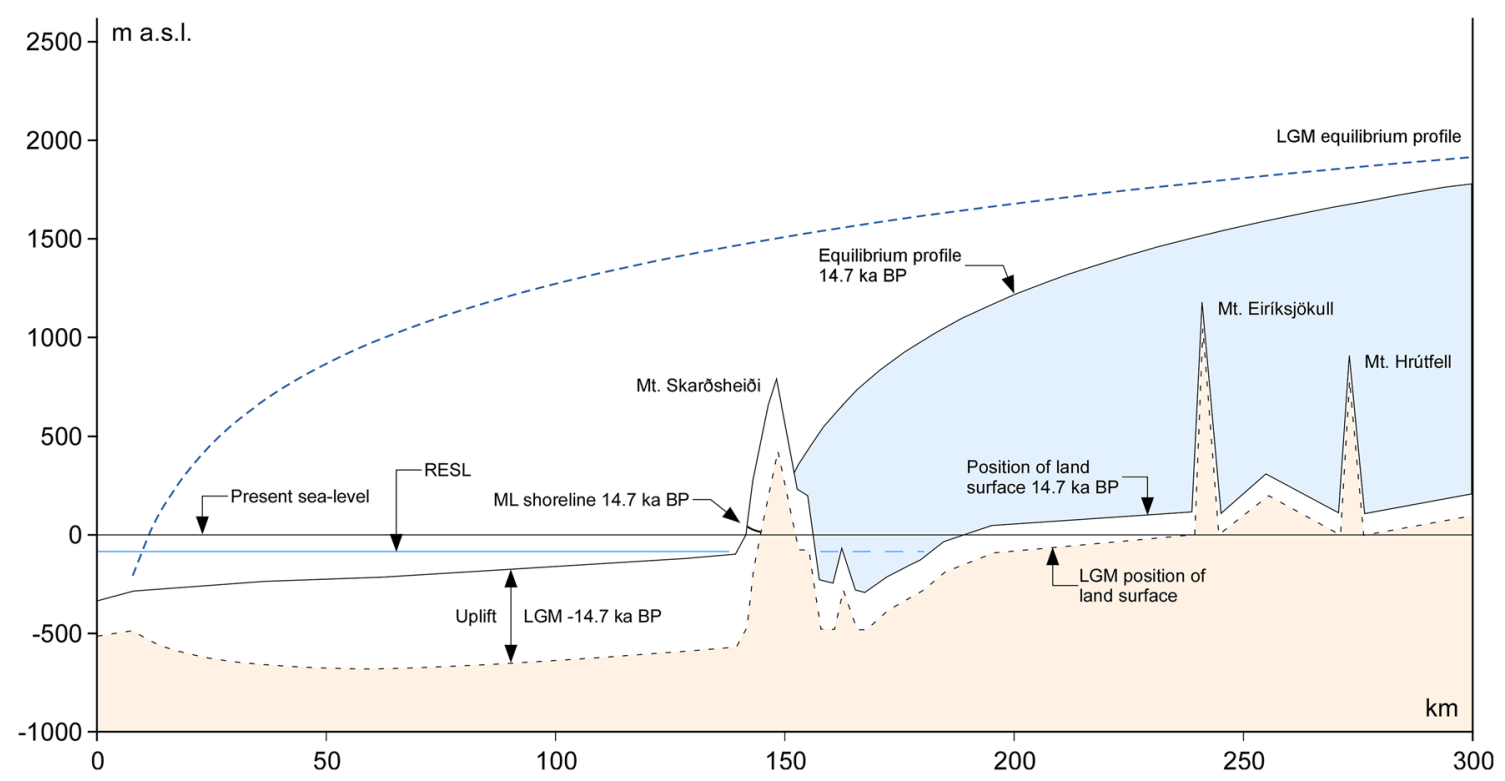

Fig. 9 The early Bølling Marine Limit (14.8-14.5 ka BP)—a balanced ice-sheet profile with an underlying crust at glacio-isostatic equilibrium in West Iceland with the Stóri-Sandhóll ML locality upwardly offset by about $90 \mathrm{~m}$. This discrepancy shows that the glacier load on the crust there must have been greater during the ML shoreline phase there (Fig. 8)

\section{Summary and discussions}

West Iceland show that RSL most likely reached its deglacial minimum between 13.7 and 13.4 ka BP (Figs. 2, 5 ) when it was lowered down to or below present sea level there, yielding a rate of glacio-isostatic uplift somewhere between +130 and $+230 \mathrm{~mm} \mathrm{a}^{-1}$. This early Bølling accelerated rate of glacio-isostatic uplift and consequent fast regression of RSL signifies that the IIS had regained an equilibrium longitudinal profile and that the ice sheet was reacting to the Bølling climatic improvement and rapidly retreating towards the interior of Iceland (Figs. 10, 11). This period of rapid retreat coincides in time with Greenland Interstadial 1 (GI-1), between about 14.7-12.9 ka BP [66], where the warmth peaked at 14.7 and $14.6 \mathrm{ka} \mathrm{BP}$ (during GI-1e). According to numerical modelling of the Icelandic ice sheet (Hubbard pers. comm., 2005, [31]) it reached its minimum at about $13.8 \mathrm{ka} \mathrm{BP}$, notably when RSL and glacier load and rate of glacio-isostatic uplift all were at temporary minima. At that time, based on 2D glacio-isostatic equilibrium modelling of the IIS, it was about $1400 \mathrm{~m}$ thick with a surface altitude close to $2000 \mathrm{~m}$ a.s.l. and a glacier load that suppressed the crust by about $-390 \mathrm{~m}$ underneath the centre of the ice sheet and about $-108 \mathrm{~m}$ at the edge while the coastal area and Mt. Skarðsheiði were fully uplifted and at a glacio-isostatic equilibrium (Fig. 10). With RESL at about $-85 \mathrm{~m}$ b.s.l. the coastline was at that time situated as far as $20 \mathrm{~km}$ outside the present-day coastline, a situation that only lasted for a very short period of time before a transgression of RSL was initiated.
Recent studies and our 2D glacio-isostatic equilibrium model have highlighted the dynamics of the IIS since LGM:

- At LGM, the volume of the IIS has been calculated to be about $3.09 \times 10^{5} \mathrm{~km}^{3}$ and the load exerted onto the crust below the IIS resulted in glacio-isostatic subsidence of about $165 \mathrm{~m}$ at its outer edge on the shelf and as much as $600 \mathrm{~m}$ below the centre of the ice sheet. The LGM ice sheet was crossing a retrograde bedrock slope on the shelf, making it susceptible to marine ice sheet instability mechanisms as it retreated under conditions of high RSL. The retreat from the maximum position was initially slow, starting some $18.6 \mathrm{ka} \mathrm{BP}$, but the shelf areas were still largely ice covered until $15.0 \mathrm{ka}$ BP.

- The marine-based section of the IIS collapsed through extremely rapid calving between 15.0 and $14.7 \mathrm{ka}$ BP. The shelf deglaciation was abrupt and by $14.7 \mathrm{ka}$ BP the ice sheet had lost about $60 \%$ of its LGM volume, or about $1.86 \times 10^{5} \mathrm{~km}^{3}$. The ML in West Iceland, at $150 \mathrm{~m}$ a.s.l., was formed during a more than 300 yearlong interval of equilibrium between RESL rise and isostatic uplift, when the IIS retreated to a position within the present coastline. Radiocarbon dates constrain the formation of the ML shoreline between 14.8 and $14.5 \mathrm{ka} \mathrm{BP}$.

- The collapse of the marine-based section of the IIS probably caused a pulse of ice rafted debris (IRD) to the 


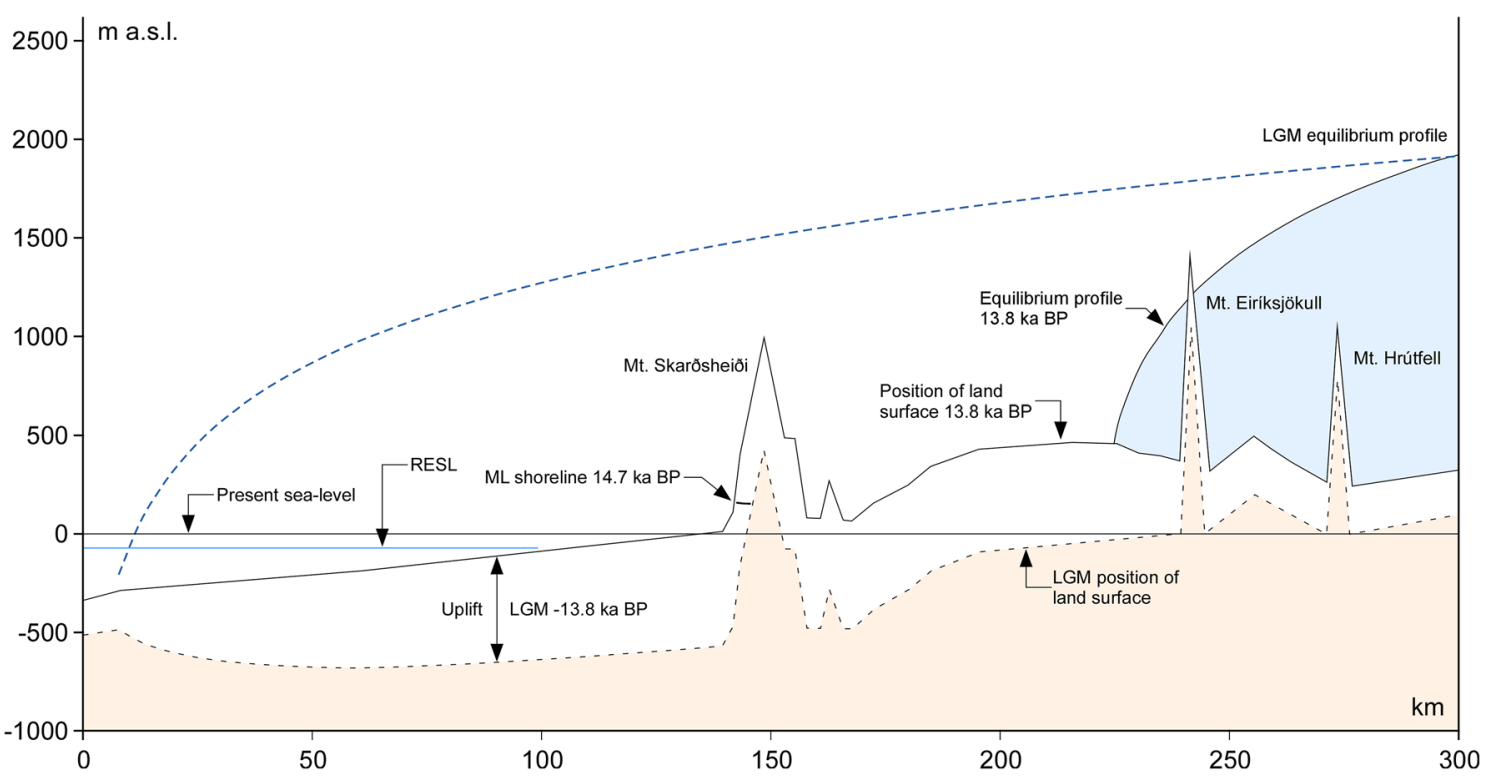

Fig. 10 The Late Weichselian minimum glacier extent (13.8 ka BP) - according to the 3D thermomechanical modelling of the IIS (Hubbard pers. comm. 2005, [31]) the IIS was at its minimum at about
$13.8 \mathrm{ka}$ BP. At that time the crust in and off coastal West Iceland was fully uplifted while it was still subsided by about $390 \mathrm{~m}$ below the centre of the ice sheet

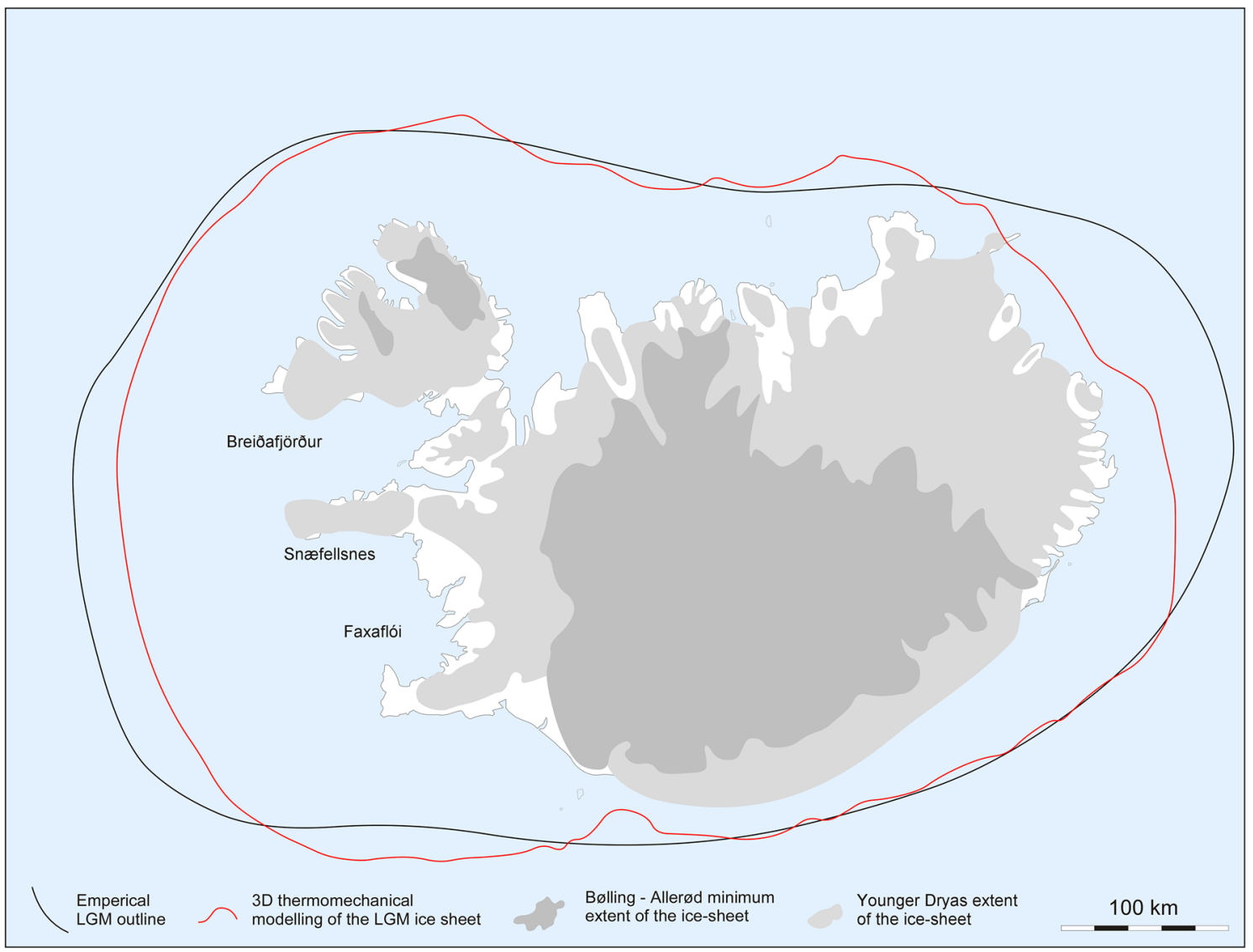

Fig. 11 Configuration of the IIS at LGM, based on empirical data (e.g. [63]) and modelling, the minimum Bølling-Allerød extent and the culmination of the YD re-advance [31] 
surrounding oceans, and a number of studies show rapid increase in North Atlantic IRD around 15.0 ka BP (e.g. [19, 74]). Andrews [2] stated that a very rapid retreat of the IIS from the Icelandic shelf areas, which he dated to $16.0-15.0 \mathrm{ka} \mathrm{BP}$, was reflected in increased IRD of Icelandic provenance in the Denmark Strait, and Geirsdóttir et al. [23] suggested that IRD peak in cores retrieved off Northwest Iceland reflected rapid deglaciation there between 15.0 and $14.6 \mathrm{ka} \mathrm{BP}$. Andrews [2] concluded that the IIS was only an important contributor to IRD in regions close to Iceland itself, and it has been shown that proportion of IRD derived from volcanic rocks clearly decreases with increasing distance from Iceland [25, 80].

- Sea level exerts control on ice sheets (e.g. [17, 42]) and a collapse of a marine-based ice sheet segment was not unique for the IIS. Landvik et al. [47] and Jakobsson et al. [39] outlined a very rapid disintegration of the marine-based Svalbard-Barents Sea ice sheet between 16.0 and $11.2 \mathrm{ka} \mathrm{BP}$, and suggested that initial deglaciation of the Barents Sea coincided with, and was likely triggered by, rising global eustatic sea levels (c.f. [47, 85]). Hormes et al. [29] showed that the rapid deglaciation of the Svalbard inner shelf areas, between 15.0 and $14.0 \mathrm{ka} \mathrm{BP}$, coincided with Mwp-1A, and that the collapse there occurred on a decadal to centennial time scale.

- Once inside the present coast, continued retreat of the IIS was controlled by rapid North Atlantic warming. The ice sheet reached its minimum Late Weichselian size at about $13.8 \mathrm{ka} \mathrm{BP}$, when it is calculated to have contained about $0.62 \times 10^{5} \mathrm{~km}^{3}$ of ice. The ice sheet had, thus, lost about $80 \%$ of its LGM volume by $13.8 \mathrm{ka} \mathrm{BP}$

- The extremely rapid $\left(+130\right.$ to $\left.+230 \mathrm{~mm} \mathrm{a}^{-1}\right)$ isostatic rebound in response to the down-wasting of the ice sheet caused a rapid regression, with RSL falling below present sea level by $13.7 \mathrm{ka}$ BP. With RESL at about $-85 \mathrm{~m}$ below present sea level the coastline was at that time situated as far as $20 \mathrm{~km}$ outside the present-day coastline.

The sequence of events during the deglaciation of Iceland highlights important causal links and complex feedbacks in the interplay between the IIS, climate, sea-level changes and isostatic adjustments:

- It agrees with the concept of marine-based ice sheet instability, where a combination of rapid RESL rise and ice sheet retreating on retrograde slope on the outer shelf could destabilize the ice sheet during the first phase of deglaciation.

- The deglaciation of IIS was characterized by three steps: (1) slow deglaciation of the outer shelf, progressing between about $18.0-15.0 \mathrm{ka}$ BP, mainly driven by sea-level rise and grounding line retreat on a retrograde slope; (2) an extremely rapid retreat from the mid-inner shelf areas between 15.0 and $14.7 \mathrm{ka} \mathrm{BP}$, mainly driven by rapid sea-level rise and large-scale calving; (3) a slower retreat driven by North Atlantic warming once the ice sheet was inside the coast, between 14.7 and $13.8 \mathrm{ka} \mathrm{BP}$.

- The period between LGM and $13.8 \mathrm{ka}$ BP was a transition between two relatively steady states of the IIS: a maximum state (where the ice sheet was in balance with climate and RESL), and a minimum state (once the ice sheet was inside the coast and reacting to mass-balance changes controlled by climate). The tipping point that led to rapid collapse of the ice sheet over the shelf areas and transition between these states was rapid rise in RESL that peaked during Mwp-1A.

Ice-ocean interaction is acknowledged to drive much of the recent increase in mass loss from both the Greenland and Antarctic ice sheets [42], primarily through forcing by increased ocean temperature. Although RESL forcing is presently quite slow compared with potential rates of forcing by oceanic warming $[1,5]$, rapid rise in RESL probably contributed significantly to the collapse of marine-based sections of Northern Hemisphere ice sheets during Termination 1 [10, 32]. The collapse of the IIS between 15.0 and $14.7 \mathrm{ka}$ BP does not confirm with linear response to warming, but rather describes non-linear response, where the ice sheet experiences an abrupt collapse once a threshold defined by RESL is crossed. We propose that the rapid RESL rise peaking during Mwp-1A and being concurrent with the collapse of the IIS strongly suggest a causal relationship between the two events. Our modelling and data supports the tentative suggestion of Ingólfsson and Norðdahl [36] that rapid sea-level rise destabilized the IIS and led to its collapse.

Acknowledgments We thank the journals reviewers for constructive comments and suggestions as how to improve the manuscript.

\section{References}

1. Alley RB, Anandakrishnan S, Dupont TK, Parizek BR, Pollard D (2007) Effect of sedimentation on ice sheet grounding-line stability. Science 315:1838-1841

2. Andrews JT (2008) The role of the Iceland Ice Sheet in the North Atlantic during the late Quaternary: a review and evidence from Denmark Strait. J Quat Sci 23:3-20

3. Andrews JT, Harðardóttir J, Helgadóttir G, Jennings AE, Geirsdóttir Á, Sveinbjörnsdóttir ÁE, Schoolfield S, Kristjánsdóttir GB, Smith LM, Thors K, Syvitski J (2000) The N and W Iceland Shelf: insights into Last Glacial Maximum ice extent and deglaciation based on acoustic stratigraphy and basal radiocarbon AMS dates. Quat Sci Rev 19:619-631 
4. Árnadóttir T, Lund B, Jiang W, Geirsson H, Björnsson H, Einarsson P, Sigurdsson T (2009) Glacial rebound and plate spreading: results from the first countrywide GPS observations in Iceland. Geophys J Int 177:691-716

5. Bamber JL, Alley RB, Joughin I (2007) Rapid response of modern day ice sheets to external forcing. Earth Planet Sci Lett 257:1-13

6. Bjarnason ITh, Schmeling H (2009) The lithosphere and asthenosphere of the Iceland hotspot from surface waves. Geophys J Int 178:394-418

7. Björnsson H (1976) Marginal and supraglacial lakes in Iceland. Jökull 26:40-51

8. Blanchon P, Shaw J (1995) Reef drowning during the last deglaciation: evidence for catastrophic sea-level rise and ice sheet collapse. Geology 23:4-8

9. Camoin GF, Seard C, Deschamps P, Webster JM, Abbey E, Braga JC, Iryu Y, Durand N, Bard E, Hamelin B, Yokoyama Y, Thomas AL, Henderson GM, Dussouillez P (2012) Reef response to sea-level and environmental changes during the last deglaciation: integrated Ocean Drilling Program Expedition 310, Tahiti Sea-level. Geology 40:643-646

10. Carlson AE, Winsor K (2012) Northern Hemisphere ice sheet responses to past climate warming. Nat Geosci 5:607-613

11. Chaytor JD, Goldfinger C, Meiner MA, Huftile GJ, Romsos CG, Legg MR (2008) Measuring vertical tectonic motion at the intersection of the Santa Cruz-Catalina Ridge and Northern Channel Islands platform, California Continental Borderland, using submerged paleoshorelines. Geol Soc Am Bull 120:1053-1071

12. Clark PU, Alley RB, Lloyd DK, Licciardi JM, Johnsen SJ, Wang $\mathrm{H}$ (1996) Origin of the first global meltwater pulse following the last glacial maximum. Paleoceanography 11:563-577

13. Clark PU, Dyke AS, Shakun JD, Carlson AE, Clark J, Wolfarth B, Mitrovica JX, Hosteler SW, McCabe M (2009) The last glacial maximum. Science 325:710-714

14. Clark PU, Shakun JD, Baker PA, Bartlein PJ, Brewer S, Brook E, Carlson AE, Cheng H, Kaufman DS, Liu ZY, Marchitto TM, Mix AC, Morrill C, Otto-Bliesner BL, Pahnke K, Russell JM, Whitlock C, Adkins JF, Blois JL, Clark J, Colman SM, Curry WB, Flower BP, He F, Johnson TC, Lynch-Stieglitz Markgraf V, McManus J, Mitrovica JX, Moreno PI, Williams JW (2012) Global climate evolution during the last deglaciation. PNAS 109:E1134-E1142

15. Compton K, Bennet RA, Hreinsdóttir S (2015) Climate driven vertical acceleration of Icelandic crust measured by CGPS geodesy. Geophys Res Lett. doi:10.1002/2014GL062446

16. Deschamps P, Durand N, Bard E, Hamelin B, Camolin G, Thomas AL, Henderson GM, Okuno J, Yokoyama Y (2012) Ice sheet collapse and sea-level rise at the Bølling warming 14,600 years ago. Nature 483:559-564

17. Denton GH, Anderson RF, Toggweiler JR, Edwards RL, Schaefer JM, Putnam AE (2010) The last glacial termination. Science 328:1652-1656

18. Eiríksson J, Knudsen KL, Hafliðason H, Henriksen P (2000) Late-glacial and Holocene palaeoceanography of the North Iceland Shelf. J Quat Sci 15:23-42

19. Elliot M, Labeyrie L, Dokken T, Manthe S (2001) Coherent patterns of ice-rafted debris deposits in the Nordic regions during the last glacial (10-60 ka). Earth Planet Sci Lett 194:151-163

20. Favier L, Cornford SL, Gudmundsson GH, Gagliardini O, GilletChaulet F, Zwinger T, Payne AG, Le Brocq AM (2014) Retreat of Pine Island Glacier controlled by marine ice sheet instability. Nat Clim Change 4:117-121

21. Fairbanks RG (1989) A 17,000-year glacio-sea-level record: influence of glacial melting rates on the Younger Dryas event and deep-ocean circulation. Nature 342:637-642
22. Fleming K, Martine Z, Wolf D (2007) Glacial-isostatic adjustment and the viscosity structure underlying the Vatnajökull ice cap, Iceland. Pure appl Geophys 164:751-768

23. Geirsdóttir Á, Andrews JT, Ólafsdóttir S, Helgadóttir G, Harðardóttir J (2002) A 36 ky record of iceberg rafting and sedimentation from north-west Iceland. Polar Res 21:91-298

24. Gray JM (1996) Glacio-isostatsy, glacio-eustasy and relative sealevel changes. In: Menzies J (ed) Past glacial environments, sediments, forms and techniques. Butterworth-Heineman, Oxford, pp 315-333

25. Grousset FE, Labeyrie L, Sinko JA, Cremer M, Bond G, Duprat J, Cortijo E, Huon S (1993) Patterns of ice-rafted detritus in the glacial North Atlantic $\left(40-55^{\circ} \mathrm{N}\right)$. Paleoceanography 8:175-192

26. Gudmundsson GH, Krug J, Durand G, Favier L, Gagliardini O (2012) The stability of grounding lines on retrograde slopes. The Cryosphere 6:1497-1505

27. Håkansson S (1983) A reservoir age for the coastal waters of Iceland. Geol Fören Stockh Förh 105:65-68

28. Hays JD, Imbrie J, Shackleton NJ (1976) Variations in Earths orbit-pacemaker of ice ages. Science 194:1121-1132

29. Hormes A, Gjermundsen EF, Rasmussen TL (2013) From mountain top to the deep sea-deglaciation in 4D of the northwestern Barents Sea ice sheet. Quat Sci Rev 75:78-99

30. Hubbard A (2006) The validation and sensitivity of a model of the Icelandic ice sheet. Quat Sci Rev 25:2297-2313

31. Hubbard A, Sugden J, Dugmore A, Norðdahl H, Pétursson HG (2006) A modelling insight into the Icelandic Late Glacial Maximum ice sheet. Quat Sci Rev 25:2283-2296

32. Hughes T (2011) A simple holistic hypothesis for the self-destruction of ice sheets. Quat Sci Rev 30:1829-1845

33. Ingólfsson Ó (1985) Late Weichselian Glacial Geology of the Lower Borgarfjördur Region, Western Iceland: a preliminary report. Arctic 38:210-213

34. Ingólfsson Ó (1987) The Late Weichselian glacial geology of the Melabakkar-Ásbakkar coastal cliffs, Borgarfjördur, W-Iceland. Jökull 37:57-80

35. Ingólfsson Ó (1988) Glacial history of the lower Borgarfjördur area, Western Iceland. Geol Fören Stockh Förh 110:293-309

36. Ingólfsson Ó, Norddahl H (2001) High relative sea-level during the Bølling Interstadial in western Iceland: a reflection of ice sheet collapse and extremely rapid glacial unloading. Arct Antarct Alp Res 33:231-243

37. Ingólfsson Ó, Norðdahl H, Hafliðason H (1995) A rapid isostatic rebound in South-western Iceland at the end of the last glaciation. Boreas 24:245-259

38. Ito T, Simons M (2011) Probing asthenospheric density, temperature, and elastic moduli below the western United States. Science 332:947-951

39. Jakobsson M, Andreassen K, Bjarnadóttir LR, Dove D, Dowdeswell JA, England JH, Funder S, Hogan K, Ingólfsson Ó, Jennings A, Larsen NK, Kirchner N, Landvik JY, Mayer L, Mikkelsen N, Möller P, Niessen F, Nilsson J, O'Regan M, Polyak L, Nørgaard-Pedersen N, Stein R (2014) Arctic Ocean glacial history. Quat Sci Rev 92:40-67

40. Jennings A, Syvitski J, Gerson L, Grönvold K, Geirsdóttir Á, Harðardóttir J, Andrews JT, Hagen S (2000) Chronology and paleoenvironments during the late Weichselian deglaciation of the south-west Iceland shelf. Boreas 29:167-183

41. Jóhannesson H, Sæmundsson K, Sveinbjörnsdóttir ÁE, Símonarson LA (1997) Nýjar aldursgreiningar á skeljum á Reykjanesskaganum. Geosci Soci Iceland Spring Meet 1997:29-30 (in Icelandic)

42. Joughin I, Alley RB, Holland DM (2012) Ice sheet response to oceanic forcing. Science 338:1172-1176

43. Kirchner N, Hutter K, Jakobsson M, Gyllencreutz R (2011) Capabilities and limitations of numerical ice sheet models: a 
discussion for Earth-scientists and modelers. Quat Sci Rev 30:3691-3704

44. Kopp RE (2012) Tahitian record suggests Antarctic collapse. Nature 483:549-550

45. Lambeck K, Yokoyama Y, Purcell T (2002) Into and out of the last glacial maximum: sea-level change during oxygen isotope stages 3 and 2. Quat Sci Rev 21:343-360

46. Lambeck K, Rouby H, Purcell A, Sun Y, Sambridge M (2014) Sea level and global ice volumes from the Last Glacial Maximum to the Holocene. Proc Natl Acad Sci 111:15296-15303

47. Landvik JY, Bondevik S, Elverhøi A, Fjeldskaar W, Mangerud J, Salvigsen O, Siegert MJ, Svendsen JI, Vorren TO (1998) The last glacial maximum of Svalbard and the Barents Sea area: ice sheet extent and configuration. Quat Sci Rev 17:43-75

48. Licciardi JM, Kurz MD, Curtice JM (2007) Glacial and volcanic history of Icelandic table mountains from cosmogenic $3 \mathrm{He}$ exposure ages. Quat Sci Rev 26:1529-1546

49. Lloyd JM, Norðdah H, Bentley MJ, Newton AJ, Tucker O, Zong Y (2009) Lateglacial to Holocene relative sea-level changes in the Bjarkarlundur area near Reykholar, North West Iceland. J Quat Sci 24:816-831

50. Magnúsdóttir B, Norðdahl H (2000) Aldur hvalbeins og fornra fjörumarka í Akrafjalli (English summary: re-examination of the deglaciation history of the area around Akrafjall in south-western Iceland). Náttúrufræðingurinn 69:177-188

51. Norddahl H (1983) Late Quaternary stratigraphy of Fnjóskadalur Central North Iceland, a study of sediments, ice-lake strandlines, glacial isostacy and ice-free areas. LUNDQUA 12:1-78

52. Norðdahl H (1991) The Weichselian and Early Holocene deglaciation history of Iceland. Jökull 40:27-50

53. Norðdahl H, Einarsson Th (2001) Concurrent changes of relative sea-level and glacier extent at the Weichselian-Holocene boundary in Berufjörður, Eastern Iceland. Quat Sci Rev 20:1607-1622

54. Norðdahl H, Pétursson HG (2005) Relative sea-level changes in Iceland. New aspects of the Weichselian deglaciation of Iceland. In: Caseldine C, Russel A, Harðardottir J, Knudsen Ó (eds) Iceland-modern processes and past environments. Elsevier, Amsterdam, pp 25-78

55. Norðdahl H, Ingólfsson Ó (2011) Younger Dryas-Preboreal glacier oscillations in Iceland, a very dynamic response to a climatic change. Arctic Paleoclimate and its Extremes (APEX), the fifth international conference and workshop. Quat Glacial Clim Extremes, 88

56. Norðdahl H, Ingólfsson Ó, Pétursson HG, Hallsdóttir M (2008) Late Weichselian and Holocene environmental history of Iceland. Jökull 58:343-364

57. Nye JF (1952) A method of calculating the thickness of the ice sheets. Nature 169:529-530

58. Pagli C, Sigmundsson F, Lund B, Sturkell E, Geirsson H, Einarsson P, Árnadóttir T, Hreinsdóttir S (2007) Glacio-isostatic deformation around the Vatnajökull ice cap, Iceland, induced by recent climate warming: GPS observations and finite element modeling. J Geophys Res 112:B08405. doi:10.1029/2006JB004421

59. Paterson WSB (1981) The physics of glaciers, 2nd edn. Pergamon Press, Oxford

60. Peltier WR (2002) On eustatic sea-level history: last Glacial Maximum to Holocene. Quat Sci Rev 21:377-396

61. Peltier WR (2004) Global glacial isostatsy and the surface of the ice-age earth: the ICE-5G (VM2) model and GRACE. Annu Rev Earth Planet Sci 32:111-149

62. Pétursson HG (1991) The Weichselian glacial history of west Melrakkaslétta, north-eastern Iceland. In: Maizels JM, Caseldine $\mathrm{C}$ (eds) Environmental changes in Iceland: past and present. Kluwer, Dordrecht, pp 49-65
63. Pétursson HG, Norðdahl H, Ingólfsson Ó (2015) Late Weichselian history of relative sea-level changes in Iceland during a collapse and subsequent retreat of marine based ice sheet. Cuadernos de Investigación Geográfica 41:261-277

64. Pollitz FF, Sacks IS (1996) Viscosity structure beneath northeast Iceland. J Geophys Res 101:17771-17793

65. Rasmussen SO, Andersen KK, Svensson AM, Steffensen JP, Vinther BM, Clausen HB, Siggaard-Andersen ML, Johnsen SJ, Larsen LB, Dahl-Jensen D, Bigler M, Rötlisberger R, Fischer H, Goto-Azuma K, Hansson ME, Ruth U (2006) A new Greenland ice core chronology for the last termination. J Geophys Res 111:D06102. doi:10.1029/2005JD006079

66. Rasmussen SO, Bigler M, Blockley SP, Blunier T, Buchardt SL, Clausen HB, Cvijanovic I, Dahl-Jensen D, Johnsen SJ, Fischer H, Gkinis V, Guillevic M, Hoek WZ, Lowe JJ, Pedro JB, Popp T, Seierstad IK, Steffensen JP, Svensson AM, Vallelonga P, Vinther BM, Walker MJC, Wheatley JJ, Winstrup M (2014) A stratigraphic framework for abrupt climatic changes during the last glacial period based on three synchronized Greenland ice-core records: refining and extending the INTIMATE event stratigraphy. Quat Sci Rev 106:14-28

67. Reimer PJ, Bard E, Bayliss A, Beck J, Blackwell PG, Bronk Ramsey C, Buck CE, Cheng H, Edwards RL, Friedrich M, Grootes PM, Guilderson TP, Haflidason H, Hajdas I, Hatté C, Heaton TJ, Hogg AG, Hughen KA, Kaiser KF, Kromer B, Manning SW, Niu M, Reimer RW, Richards DA, Scott EM, Southon JR, Turney CSM, van der Plicht J (2013) IntCal13 and MARINE13 radiocarbon age calibration curves 0-50000 years cal BP. Radiocarbon 55:1869-1887

68. Roberts MJ, Pálsson F, Gudmundsson MT, Björnsson H, Tweed FS (2005) Ice-water interaction during floods from Grænalón glaciar-dammed lake, Iceland. Ann Glaciol 40:133-138

69. Rundgren M, Ingólfsson Ó, Björck S, Jiang H, Haflidason $\mathrm{H}$ (1997) Dynamic sea-level change during the last deglaciation of northern Iceland. Boreas 26:201-215

70. Schoof C (2007) Ice sheet grounding line dynamics: Steady states, stability, and hysteresis. J Geophys Res 112:F03S28. doi:10.1029/2006JF000664

71. Sigmundsson F (1990) Seigja jarðar undir Íslandi, samanburður líkanreikninga við jarðfræðileg gögn (English summary: Viscosity of the Earth beneath Iceland, comparison of model calculations with geological data). Háskólaútgáfan, Reykjavík

72. Sigmundsson F (1991) Post-glacial rebound and asthenosphere viscosity in Iceland. Geophys Res Lett 18:1131-1134

73. Sjöberg LE, Pan M, Erlingsson S, Asenjo E, Árnason K (2004) Land uplift near Vatnajökull, Iceland, as observed by GPS in 1992, 1996 and 1999. Geophys J 159:943-948

74. Small D, Austin W, Rinterknecht V (2013) Freshwater influx, hydrographic reorganization and the dispersal of ice-rafted detritus in the sub-polar North Atlantic Ocean during the last deglaciation. J Quat Sci 28:527-535

75. Spagnolo M, Clark CD (2009) A geomorphological overview of glacial landform on the Iceland continental shelf. J Maps 5:37-42

76. Stuvier M, Reimer PJ (1993) Extended ${ }^{14} \mathrm{C}$ database and revised CALIB radiocarbon calibration program. Radiocarbon $35: 215-230$

77. Syvitski J, Jennings AE, Andrews JT (1999) High-resolution seismic evidence for multiple glaciation across the southwest Iceland Shelf. Arct Antarct Alp Res 31:50-57

78. Sæmundsson K (1991) Jarðfræði Kröflukerfisins. In: Garðarsson A, Einarsson Á (eds) Náttúra Mývatns. Hið íslenska náttúrufræđifélag, Reykjavík, pp 22-95 (in Icelandic)

79. Thornalley DJR, McCave IN, Elderfield H (2010) Freshwater input and abrupt deglacial climate change in the North Atlantic. Paleoceanography 25:PA1201. doi:10.1029/2009PA001772 
80. Verplanck EP, Farmer GL, Andrews J, Dunhill G, Millo G (2009) Provenance of Quaternary glacial and glacimarine sediments along the southeast Greenland margin. Earth Planet Sci Lett 286:52-62

81. Valdimarsson H, Malmberg S-A (1999) Near-surface circulation in Icelandic waters derived from satellite tracked drifters. J Mar Res Inst 16:23-39

82. Walcott RI (1970) Isostatic response to loading of the crust in Canada. Can J Earth Sci 7:716-727
83. Weertman J (1974) Stability of the junction of an ice sheet and an ice shelf. J Glaciol 13:3-11

84. Weertman J (1976) Milankovitch solar-radiation variations and ice age ice sheet sizes. Nature 261:17-20

85. Winsborrow MCM, Andreassen K, Corner GD, Laberg JS (2010) Deglaciation of a marine-based ice sheet: late Weichselian palaeo-ice dynamics and retreat in the southern Barents Sea reconstructed from onshore and offshore glacial geomorphology. Quat Sci Rev 29:424-442 